\title{
Southern Ocean ecosystem response to Last Glacial Maximum boundary conditions
}

\author{
Himadri Saini ${ }^{1,2}$, Karin Kvale ${ }^{3,4}$, Zanna Chase ${ }^{5}$, Karen E. Kohfeld ${ }^{6}$, Katrin J. \\ Meissner $^{1,2}$, Laurie Menviel ${ }^{1}$ \\ ${ }^{1}$ Climate Change Research Centre, University of New South Wales, Sydney, New South Wales, Australia \\ ${ }^{2}$ The Australian Research Council Centre of Excellence for Climate Extremes, Sydney, New South Wales, \\ Australia \\ ${ }^{3}$ GEOMAR Helmholtz Centre for Ocean Research, West shore campus, Duesternbrooker Weg 20, Kiel, \\ Germany \\ ${ }^{4}$ Current address: GNS Science, 1 Fairway Drive, Avalon 5010, PO Box 30368, Lower Hutt 5040, NZ \\ ${ }^{5}$ Australian Antarctic Program Partnership, Institute for Marine and Antarctic Studies, University of \\ Tasmania, Hobart, Tasmania, Australia \\ ${ }^{6}$ School of Resource and Environmental Management, Simon Fraser University, 888 University Drive,
} Burnaby, BC, V5A 1S6, Canada

\section{Key Points:}

- Weaker oceanic circulation and lower ocean temperatures lead to lower net primary productivity at the LGM compared to PI.

- Physical drivers such as SST, sea ice and ventilation depth determine the changes in phytoplankton functional type distribution.

- Iron fertilisation amplifies ecosystem changes and leads to $4.4 \%$ higher export production in the Southern Ocean at the LGM compared to PI.

Corresponding author: Himadri Saini, himadri.saini@student.unsw.edu.au

This article has been accepted for publication and ${ }^{-1}$ undergone full peer review but has not been through the copyediting, typesetting, pagination and proofreading process, which may lead to differences between this version and the Version of Record. Please cite this article as doi: 10.1029/2020PA004075. 


\begin{abstract}
Phytoplankton exert a significant control on the marine carbon cycle and can thus impact atmospheric $\mathrm{CO} 2$ concentration. Here we use a new ecosystem model to analyse the response of diatoms and coccolithophores in the Southern Ocean to Last Glacial Maximum (LGM) climate conditions, and changes in aeolian iron (Fe) input in the Southern Ocean. We find that LGM climate conditions without changes in Fe input lead to a large increase in diatoms north of the winter sea ice edge in the South Atlantic (19\%) and the South Pacific (26\%), and a $31 \%$ and $9 \%$ increase within the seasonal sea-ice zone in the South Atlantic and Indian oceans, respectively, while diatoms decrease in the Ross and Weddell Seas, and in the South Pacific $(62 \%)$ south of the winter sea ice edge. Coccolithophores increase by $11 \%$ in the South West Atlantic near $45^{\circ} \mathrm{S}$ but are outcompeted by diatoms within the seasonal sea-ice zone, where they decrease by $21 \%$. Overall, this results in a $11 \%$ decrease in Southern Ocean net primary productivity (NPP) and a $2.4 \%$ decrease in export production (EP). A series of sensitivity experiments with different aeolian Fe input are compared to available paleo-proxy records. The best fit is obtained for a simulation forced with dust fluxes from Lambert et al. (2015) and reduced Antarctic Bottom Water formation in the Weddell Sea. The $78 \%$ increase in aeolian Fe input in the Southern Ocean in this simulation increases the Southern Ocean EP by $4.4 \%$, while NPP remains $8.7 \%$ weaker compared to preindustrial.
\end{abstract}

\title{
1 Introduction
}

Marine ecosystems are responsible for more than $40 \%$ of the total primary productivity on Earth (Baumert \& Petzoldt, 2008; Simon et al., 2009), and play a key role in the global carbon cycle on centennial to millennial timescales (Ducklow et al., 2001; Sarmiento et al., 2004; Sarmiento \& Gruber, 2006; Mariotti et al., 2012; Herndl \& Reinthaler, 2013) by exporting carbon from the surface into the deep ocean via the biological pump. The net efficiency of the biological carbon export depends partly on the relative competitive fitness of a variety of phytoplankton functional types (Kvale et al., 2015b, 2019). Major groups of these plankton include diazotrophs, coccolithophores, and diatoms. These groups differ in size, shape, and cell wall composition, which affect their sinking velocities (Klaas \& Archer, 2002; Miklasz \& Denny, 2010; Collins et al., 2014) and thus the amount of carbon exported into the deep ocean (DeVries et al., 2012). Calcifiers (e.g. coccolithophores) and silicifiers (e.g. diatoms) are two functional types thought to exert a dominant influence on global carbon cycling (Matsumoto et al., 2002) due to both their relatively efficient carbon export properties as well as their dominance in the Southern Ocean. Both diatoms and coccolithophores photosynthesize, which leads to oceanic $\mathrm{CO}_{2}$ uptake. However, coccolithophores also produce calcite platelets, which leads to a decrease in surface alkalinity, that induces a net $\mathrm{CO}_{2}$ outgassing (a mechanism also called the calcium carbonate counter-pump). Diatoms tend to dominate export production (EP) in the High Nutrient Low Chlorophyll (HNLC) regions. As EP is limited by the availability of Fe in HNLC regions, it has been hypothesized that iron fertilization of HNLC regions might be an efficient mechanism for enhancing ocean sequestration of carbon both in the modern climate as well as in the past (Martin, 1990).

It is therefore important to better constrain the response of ecosystems to climatic changes, and in particular the response of diatoms and coccolithophores in the Southern Ocean. One example of significantly different climate conditions is the Last Glacial Maximum (LGM, $\sim 21,000$ years ago), during which the concentration of atmospheric $\mathrm{CO}_{2}$ was $190 \mathrm{ppm}$ (Marcott et al., 2014), and sea-level was $\sim 130 \mathrm{~m}$ lower (Lambeck et al., 2014) than today, with ice-sheets covering North America, Scandinavia and Siberia (Charbit et al., 2007). Despite significant progress in recent years, there are still significant uncertainties associated with the quantitative contribution of the different processes that led to the $\sim 90 \mathrm{ppm}$ atmospheric $\mathrm{CO}_{2}$ decrease during the last glaciation (e.g. Kohfeld 
and Ridgwell (2009), Menviel et al. (2012),Kobayashi et al. (2015), Jeltsch-Thömmes et al. (2019), Khatiwala et al. (2019)). Surface ocean temperatures were up to $10^{\circ} \mathrm{C}$ lower in the mid North Atlantic, and $2-6^{\circ} \mathrm{C}$ lower in the Southern Ocean at the LGM compared to pre-industrial (PI) times (Waelbroeck et al., 2009). These globally colder conditions, and associated changes in sea-ice extent, might have led to significant changes in phytoplankton distributions. For example, diatom abundance records north of the Antarctic Polar front during the LGM are associated with a major northward winter sea-ice extension in the Southern Ocean (Gersonde et al., 2005; Benz et al., 2016). Furthermore, as there is some evidence that smaller cell-sized plankton might have a competitive advantage over larger cell-sized ones in warmer conditions (i.e., coccolithophores over diatoms) (Marinov et al., 2010), lower temperatures during the LGM might have been advantageous for diatoms.

In addition, as the LGM was globally drier and windier, the aeolian input of dust, and therefore Fe and silica input into the ocean, was most likely higher (Harrison et al., 2001; Kohfeld \& Harrison, 2001; McGee et al., 2010; Lambert et al., 2015; Kienast et al., 2016; Shoenfelt et al., 2018; Ohgaito et al., 2018). As Fe is a limiting nutrient today, a greater Fe flux might have enhanced marine productivity (Martin, 1990). This is hypothesized to have been especially effective in the Southern Ocean, resulting in a higher export of organic carbon into deep ocean layers, thus contributing to a decrease in atmospheric $\mathrm{CO}_{2}$ concentrations (Martínez-García et al., 2014; Lambert et al., 2021). For example, reconstructed glacial Fe fluxes and productivity proxies from Southern Ocean cores show a strong correlation between increased lithogenic flux in the subantarctic zone and low atmospheric $\mathrm{CO}_{2}$ concentrations (Martínez-García et al., 2014; Graham et al., 2015).

The complexity of ecosystems and dependence between different plankton groups, especially during glacial times, is not well understood and warrants more research. Earlier studies on glacial iron fertilisation (Bopp et al., 2003; Oka et al., 2011; Lambert et al., 2015; Muglia et al., 2017; Yamamoto et al., 2019) have used different biogeochemical models for investigating the role of marine plankton on glacial primary productivity and EP. However, none of these LGM iron fertilisation studies were performed with a model including explicit prognostic equations for both coccolithophores and diatoms. In this study, we use a newly developed, state-of-the-art ecosystem model (Kvale et al., 2020), which includes four distinct classes of phytoplankton such as, explicit calcifiers and explicit silicifiers in addition to general phytoplankton, diazotrophs, and zooplankton. Along with the nutrients, calcium carbonate, silica and iron cycling are incorporated in this model. We therefore have a more resolved ecosystem network to simulate global plankton community dynamics. We analyse the simulated differences in phytoplankton distributions, NPP and EP under LGM climate boundary conditions compared to PI boundary conditions in the Southern Ocean. We also explore the impact of varying aeolian Fe and silica input into the Southern Ocean by performing a set of sensitivity experiments.

\section{Methods}

\subsection{Model Description}

The model used in this study is the University of Victoria Earth System Climate Model (UVic ESCM) version 2.9. It consists of the ocean general circulation model MOM2 (Pacanowski, 1995), coupled to a dynamic-thermodynamic sea-ice model based on Semtner (1976), Hibler (1979) and Hunke and Dukowicz (1997), with a spatial resolution of $1.8^{\circ}$ by $3.6^{\circ}$ and 19 ocean depth levels. It also includes a vertically integrated two-dimensional atmospheric energy moisture balance model (Fanning \& Weaver, 1996), a land surface scheme (Meissner et al., 2003), a dynamic vegetation model (Meissner et al., 2003) and a sediment model (Archer \& Maier-Reimer, 1994; Meissner et al., 2012). The model is driven by seasonal variations in solar insolation at the top of the atmosphere and seasonallyvarying wind stress and wind fields (Kalnay et al., 1996). A full description of the model 
physics and structure can be found in Weaver et al. (2001), Meissner et al. (2003), Eby et al. (2009), Mengis et al. (2020).

The ocean carbon cycle is based on the new Kiel Marine Biogeochemical Model version 3 (KMBM3, Kvale et al. (2020)). It is a Nutrient Phytoplankton Detritus Zooplankton (NPDZ) model (Schmittner et al., 2005) which now includes prognostic silica, prognostic $\mathrm{CaCO}_{3}$ (calcium carbonate), as well as silicifying plankton (diatoms) and calcifying plankton (coccolithophores) (Kvale et al., 2015a, 2015b). The model also incorporates a prognostic iron cycle (Nickelsen et al., 2015), which features hydrothermal sources (Yao et al., 2019). The model therefore now comprises general phytoplankton, nitrogen fixers (diazotrophs), calcifiers, silicifiers, zooplankton with a new zooplankton grazing parameterisation, freely sinking and $\mathrm{CaCO}_{3}$ ballasted detritus (representing particulate organic carbon, or POC), $\mathrm{CaCO}_{3}$ (representing particulate inorganic carbon, or PIC), and dissolved nitrate, oxygen, phosphate, iron, alkalinity, dissolved inorganic carbon (DIC) and silica. Different phytoplankton functional types have unique half saturation constants for nutrient uptake and thus compete with each other for nutrients and light. In addition, ocean temperature affects the total growth rate of plankton. All biogeochemical parameter values and model-related equations can be found in Kvale et al. (2020). Of particular interest to this study are the different growth rates for diatoms and coccolithophores (0.76 day ${ }^{-1}$ and 0.6 day $\left.^{-1}\right)$, respectively) and half saturation constants for Fe uptake $\left(0.12 \mathrm{nmol} \mathrm{m} \mathrm{m}^{-3}\right.$ and $0.1 \mathrm{nmol} \mathrm{m}^{-3}$, respectively). These parameters advantage diatoms in high nutrient environments, and in environments with short growing seasons. The zooplankton grazing preferences are identical for both coccolithophores and diatoms in this model, and therefore grazing selectivity does not exert a different effect on either phytoplankton functional type.

\subsection{Experimental design}

The simulations are integrated under two background climatic conditions: LGM and PI. The PI simulations are forced with an atmospheric $\mathrm{CO}_{2}$ concentration of 283.86 ppm (Marcott et al., 2014) and orbital parameters corresponding to the year 1800 (Berger, 1978). The LGM simulations are forced with orbital parameters corresponding to year $21 \mathrm{ka}$ BP (Berger, 1978), and a global ice-sheet extent, topography and albedo corresponding to $21 \mathrm{ka} \mathrm{BP}$ (Peltier, 1994) as well as an atmospheric $\mathrm{CO}_{2}$ concentration of 189.65 ppm (Marcott et al., 2014). A subgrid bathymetry parameterisation is used to represent finer-scale processes relevant to iron cycling at the bottom of the ocean where the sediment to water column transfer occurs. This is done in order to account for the actual bathymetry of the ocean floor which is not well resolved in a coarse resolution ocean model (Nickelsen et al., 2015). It is adjusted to the LGM sea-level (Somes et al., 2017) and applied to the biogeochemical module of the ocean model without affecting the model grid for ocean physics. The PI and the control LGM simulations (called PI and LGM-clim hereafter) are forced with aeolian dust inputs based on the BASE-PI simulation of Mahowald et al. (2006) (Fe-PI and Si-PI). To obtain aeolian Fe input, we multiply the dust fluxes with a two-dimensional field of Fe and silica dust content based on Zhang et al. (2015) (Figure S1). We further apply a 1\% solubility factor (Mahowald et al., 2009; Schroth et al., 2009) to the resulting Fe flux. Both PI and LGM-clim simulations are integrated for 10,000 years to reach an equilibrium state.

From this LGM-clim equilibrium simulation, we integrate a suite of LGM sensitivity experiments to assess the impact of changes in aeolian Fe and silica input on ecosystems (Table 1), using four different iron masks (Fe-PI, Fe-BASE-LGM, Fe-lamb-LGM, Fe-glac-LGM) and two different silica masks (Si-PI and Si-BASE-LGM) (Figure 1). The method to convert dust fluxes into Fe and Si fluxes is described above and is the same for all masks. The first sensitivity simulation, LGM-BASE-ref, is integrated with LGM iron and silicate dust fluxes (Fe-BASE-LGM, Si-BASE-LGM) based on the BASE-LGM simulation of Mahowald et al. (2006). The other sensitivity study (LGM-glac, described 

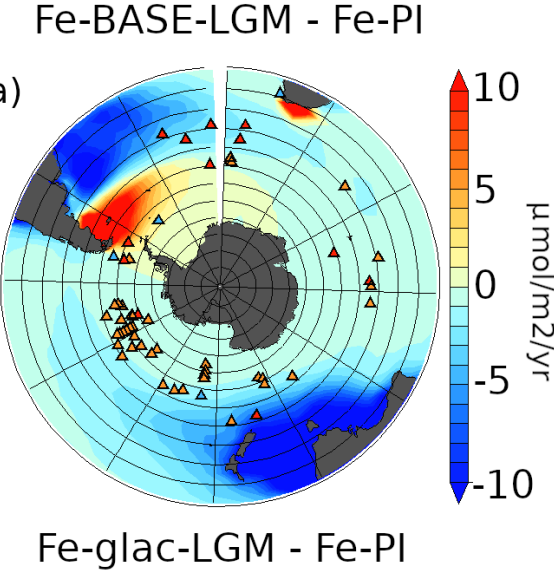

(c)

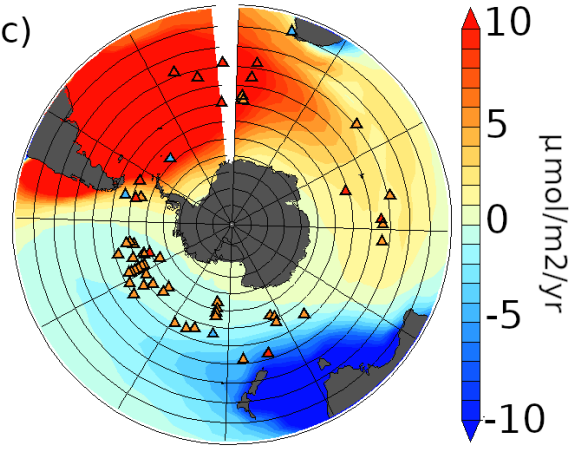

Fe-lamb-LGM - Fe-PI

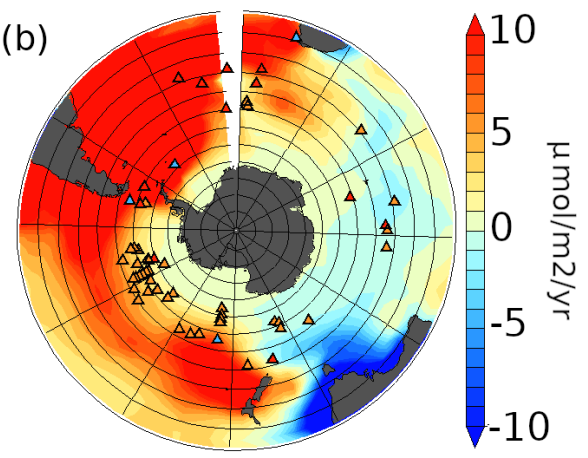

Si-BASE-LGM - Si-PI

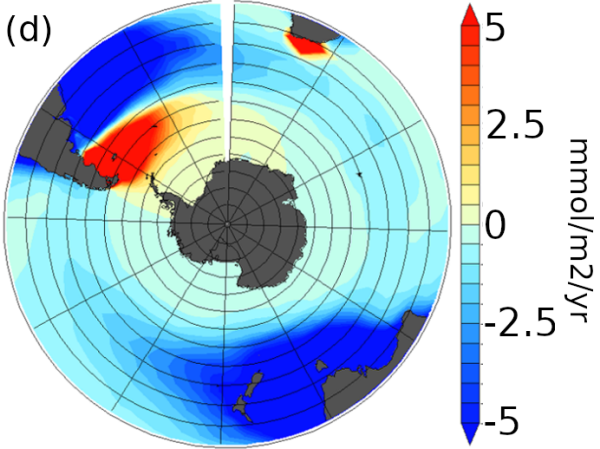

Figure 1. Anomalies of iron and silica dust fluxes between LGM and PI. (a) Fe-BASELGM minus Fe-PI (Mahowald et al., 2006; Zhang et al., 2015), (b) Fe-lamb-LGM minus Fe-PI (Mahowald et al., 2006; Lambert et al., 2015; Zhang et al., 2015), (c) Fe-glac-LGM minus Fe-PI (Mahowald et al., 2006; Ohgaito et al., 2018; Zhang et al., 2015), (d) Si-BASE-LGM minus Si-PI (Mahowald et al., 2006; Zhang et al., 2015). Iron fluxes are shown in $\mu \mathrm{mol} \mathrm{m}^{-2} \mathrm{yr}^{-1}$, silica fluxes in $\mathrm{mmol} \mathrm{m} \mathrm{m}^{-2} \mathrm{yr}^{-1}$; triangles show proxies of lithogenic dust flux anomalies between LGM and Holocene; dark (light) orange represents significantly higher (slightly higher) and dark (light) blue represents significantly lower (slightly lower) dust during LGM compared to Holocene. 
Table 1. List of experiments and associated climatic boundary conditions and aeolian Fe and Si inputs.

\begin{tabular}{|c|c|c|c|c|c|}
\hline Experiments & Climate & Aeolian iron input & $\begin{array}{l}\text { Global Fe dust } \\
\text { flux into the ocean } \\
\text { (Gmoles/yr) }\end{array}$ & $\begin{array}{l}\text { Fe dust flux } \\
\text { into the South- } \\
\text { ern Ocean } \\
\left(30^{\circ} \mathrm{S}: 90^{\circ} \mathrm{S}\right)\end{array}$ & Silica mask \\
\hline $\begin{array}{l}\text { PI } \\
\text { LGM-clim } \\
\text { LGM-BASE-HFe } \\
\text { LGM-BASE-HSi } \\
\text { LGM-BASE-ref } \\
\text { LGM-lamb } \\
\text { LGM-glac } \\
\text { LGM-W }\end{array}$ & $\begin{array}{l}\text { PI } \\
\text { LGM } \\
\text { LGM } \\
\text { LGM } \\
\text { LGM } \\
\text { LGM } \\
\text { LGM } \\
\text { LGM (with } \\
\text { reduced } \\
\text { AABW for- } \\
\text { mation) }\end{array}$ & $\begin{array}{l}\text { Fe-PI } \\
\text { Fe-PI } \\
\text { Fe-BASE-LGM } \\
\text { Fe-PI } \\
\text { Fe-BASE-LGM } \\
\text { Fe-lamb-LGM } \\
\text { Fe-glac-LGM } \\
\text { Fe-lamb-LGM }\end{array}$ & $\begin{array}{l}3.47 \\
3.47 \\
7.037 \\
3.47 \\
7.037 \\
9.072 \\
6.532 \\
9.072\end{array}$ & $\begin{array}{l}0.2279 \\
0.2279 \\
0.2213 \\
0.2279 \\
0.2213 \\
1.031 \\
1.513 \\
1.031\end{array}$ & $\begin{array}{l}\text { Si-PI } \\
\text { Si-PI } \\
\text { Si-PI } \\
\text { Si-BASE-LGM } \\
\text { Si-BASE-LGM } \\
\text { Si-BASE-LGM } \\
\text { Si-BASE-LGM } \\
\text { Si-BASE-LGM }\end{array}$ \\
\hline
\end{tabular}

below) uses the glaciogenic mask from Ohgaito et al. (2018), based on the Tune 1 dust flux from Mahowald et al. (2006) but with a lower dust loading.

In order to disentangle the ecosystem response to changes in $\mathrm{Fe}$ and silicate fluxes, we also run an experiment forced with LGM climate boundary conditions, LGM iron fluxes and PI silica fluxes (LGM-BASE-HFe), and another LGM experiment forced with LGM silicate fluxes and PI iron fluxes (LGM-BASE-HSi). The globally integrated silica dust flux for PI (Si-PI) is 21 Tmoles ( $10^{12}$ moles) per year and 36.5 Tmoles per year for LGM (Si-BASE-LGM), with a plume of higher silica input in the South Atlantic originating from Patagonia at the LGM compared to PI (Fig. 1d). However, the overall prescribed silica flux is reduced by $55 \%$ during the LGM in the Southern Ocean south of $30^{\circ} \mathrm{S}$.

The globally integrated values for different iron masks (Table 1) are within the range listed in previous studies (Hopcroft et al., 2015; Lambert et al., 2015; Pasquier \& Holzer, 2018). Fe-PI iron flux to the surface ocean is 3.47 Gmoles $\left(10^{9}\right.$ moles $) \mathrm{Fe} / \mathrm{yr}$ while FeBASE-LGM amounts to 7.037 Gmoles Fe/yr and therefore corresponds to a $50 \%$ iron flux increase during LGM compared to PI. However, there is a small decrease in Fe input into the Southern Ocean in Fe-BASE-LGM compared to Fe-PI (0.2213 compared to $0.2279 \mathrm{Gmol} / \mathrm{yr})$.

To include scenarios with an enhanced LGM aeolian Fe flux into the Southern Ocean, we thus perform two additional LGM experiments. These experiments are forced with LGM dust fluxes from Lambert et al. (2015) (called Fe-lamb-LGM hereafter), and with glaciogenic dust fluxes based on a simulation by Ohgaito et al. (2018) (called Fe-glacLGM hereafter) (Table 1). The globally integrated iron fluxes into the ocean amount to 9.072 Gmoles/yr and 6.532 GMoles/yr for LGM-lamb and LGM-glac, respectively. They therefore represent a global 2 to 3 fold increase in aeolian iron input at the LGM compared to PI. Table 1 shows that the LGM iron flux is also increased regionally by a factor of 2 to 3 over the Southern Ocean.

We perform an additional sensitivity experiment (LGM-W), which tests the effect of a change in Southern Ocean circulation on ecosystem distribution. In this experiment, the Antarctic Bottom Water (AABW) formation in the Weddell Sea is weakened by adding $0.1 \mathrm{~Sv}$ of freshwater between $54^{\circ} \mathrm{W}: 30^{\circ} \mathrm{W}$ and $64^{\circ} \mathrm{S}: 74^{\circ} \mathrm{S}$. This experiment is forced with the Fe-lamb-LGM iron mask (since this is the most consistent with the proxy records, as discussed below) and the Si-BASE-LGM silica mask.

\subsection{Model Data comparison}

We compare the LGM-PI iron dust flux anomalies used in this study, which are based on earlier studies by Mahowald et al. (2006); Lambert et al. (2015); Ohgaito et al. (2018), with proxy records of LGM-Holocene lithogenic flux anomalies. To build the database 
of lithogenic flux anomalies, we compiled estimates of total lithogenic flux to the seafloor based on ${ }^{230} \mathrm{Th}$ normalisation and ${ }^{232} \mathrm{Th}$ concentrations (Kienast et al., 2016) from 90 Southern Ocean cores (Francois et al., 1993; Frank et al., 1995, 2000; Kumar et al., 1995; Labeyrie et al., 1996; Dezileau et al., 2000; Chase et al., 2003; Anderson et al., 2009, 2014; Bradtmiller et al., 2009; Martínez-Garcia et al., 2009; Negre et al., 2010; Lippold et al., 2012; Jaccard et al., 2013; Lamy et al., 2014; Studer et al., 2015; Durand et al., 2017). Age models and derived fluxes were taken as published. LGM values for each core represent an average of observations between 28-18 ka BP, and Holocene values represent an average of observations between 10-0 ka BP.

The qualitative comparison between our new database of observed lithogenic flux anomalies and the aeolian flux anomalies used to force our model is shown in Figure 1. The best agreement is achieved by the dust flux of Lambert et al. (2015) (Figure 1b), which suggests a higher dust input into the South Pacific during the LGM, whereas the other dust reconstructions show a lower dust input in that region compared to PI (Mahowald et al., 2006; Ohgaito et al., 2018).

We compare anomalies in simulated diatom abundance in the surface water column with anomalies in opal flux proxies, and simulated EP anomalies at $177.5 \mathrm{~m}$ depth with EP anomalies compiled in Kohfeld et al. (2013). Changes in EP are based on a combination of proxies (Kohfeld et al., 2013). The proxy of opal flux considers changes in opal rain recorded in sediment cores using a constant flux proxy to account for sediment redistribution. Both opal and export proxies represent changes that are archived in marine sediments and represent qualitative differences between LGM and Holocene. We also compare our simulated opal flux at the ocean-sediment interface with the opal proxy compilation (Figure S2). We find that the spatial distribution of diatom abundance and opal fluxes at the bottom of the ocean are highly correlated in the model. The model data comparison is qualitative: we provide a simple metric of fit based on the sign of simulated anomaly versus proxy anomaly by counting matches and mismatches at each proxy location.

\section{Results}

\subsection{Simulated LGM Southern Ocean surface conditions}

In this section, we compare the LGM-clim simulation to the PI control simulation (PI) with both simulations being forced with the same PI iron and silicate fluxes. The simulated LGM sea surface temperature (SST) anomalies, shown in Figure 2a, are broadly consistent with reconstructed LGM SST data (Waelbroeck et al., 2009; Annan \& Hargreaves, 2013).

There is a significant advance of sea-ice in the Southern Ocean, with the simulated LGM austral winter sea-ice edge located at $51^{\circ} \mathrm{S}$ in the Atlantic and Indian sectors and at $57^{\circ} \mathrm{S}$ in the Pacific sector. The austral summer sea-ice edge reaches $56^{\circ} \mathrm{S}$ in the Atlantic and Indian sectors and $60-63^{\circ} \mathrm{S}$ in the Pacific sector (Figure 2a). These results are consistent with the recent PMIP3 multi-model mean estimates of austral winter and summer sea-ice extents of $51.5^{\circ} \mathrm{S}$ and $60.5^{\circ} \mathrm{S}$, respectively (Green et al., 2020). The mean Southern Ocean $\left(45^{\circ} \mathrm{S}-75^{\circ} \mathrm{S}\right)$ austral summer and austral winter SSTs are respectively $2^{\circ} \mathrm{C}$ and $1^{\circ} \mathrm{C}$ lower in the LGM simulation compared to the PI simulation, consistent with summer SST estimates from Gersonde et al. (2005). A strong SST decrease is simulated north of $\sim 55^{\circ} \mathrm{S}$ with less cooling south of it, in agreement with Kohfeld et al. (2013), and the smallest anomalies are within the permanent sea-ice region (south of the PI summer sea-ice edge). Under LGM conditions, deep-water formation is enhanced in both the Weddell and Ross Seas (Figure 2b), with implications for surface nutrient concentrations as detailed below. 

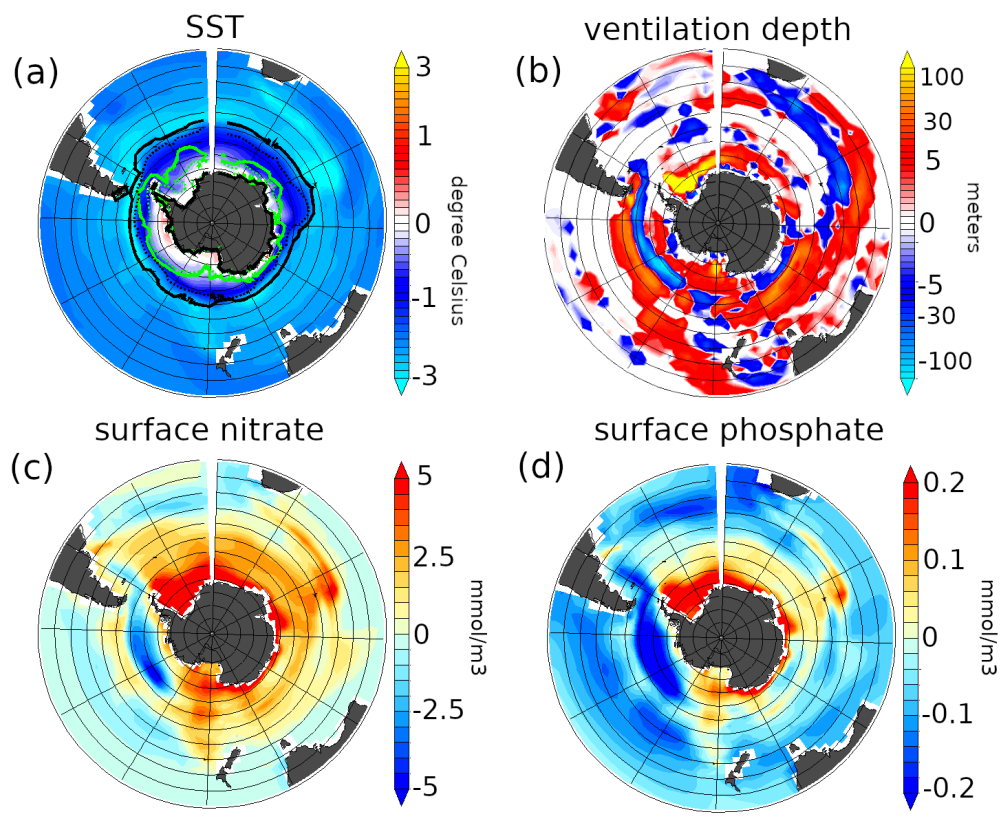

surface dFe
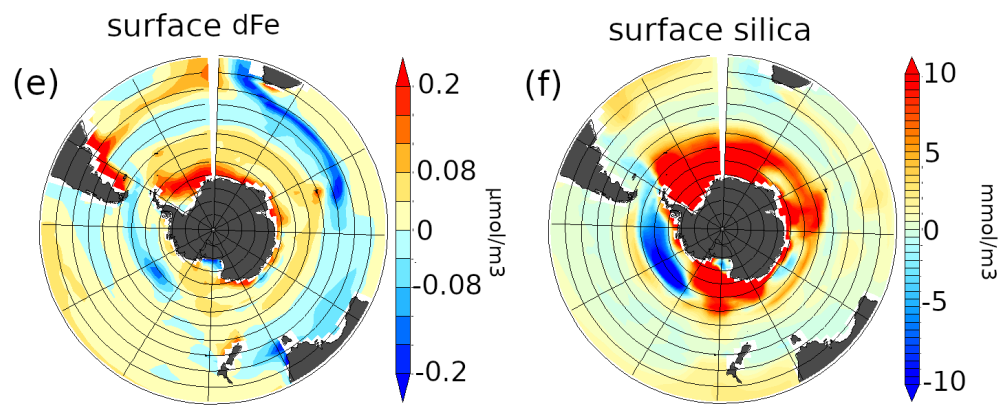

Figure 2. LGM-clim to PI anomalies of annual mean (a) sea surface temperatures $\left({ }^{\circ} \mathrm{C}\right)$ with contours of mean $15 \%$ ocean ice concentration during LGM austral winter (JJA, solid black), austral summer (DJF, solid green), PI austral winter (dashed black) and austral summer (dashed green); (b) ocean ventilation depth (meters). Please note the intervals are non linear in both (a) and (b); 0 - 240m depth averaged (c) $\mathrm{NO}^{3-}\left(\mathrm{mmol} \mathrm{m}^{-3}\right)$, (d) $\mathrm{PO}_{4}^{3-}\left(\mathrm{mmol} \mathrm{m}^{-3}\right),(\mathrm{e}) \mathrm{dFe}(\mu \mathrm{mol}$ $\mathrm{m}^{-3}$ ) and (f) silica concentrations $\left(\mathrm{mmol} \mathrm{m}^{-3}\right)$. 
$\mathrm{PI}$

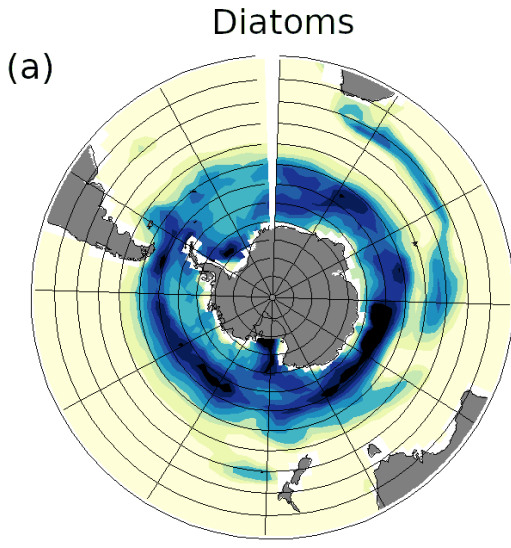

EP

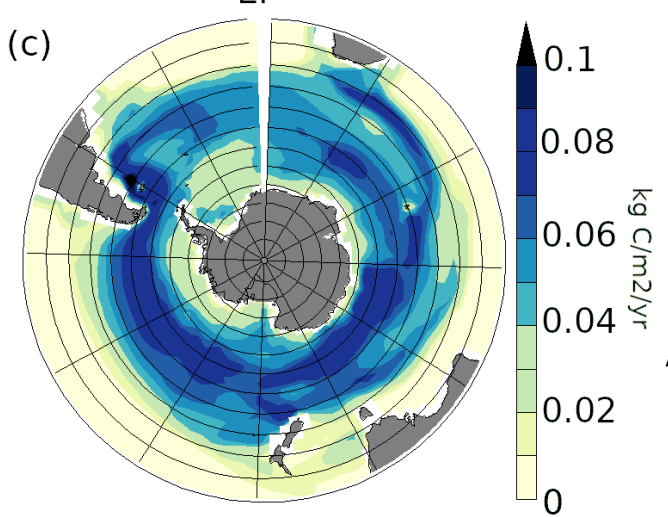

Coccolithophores

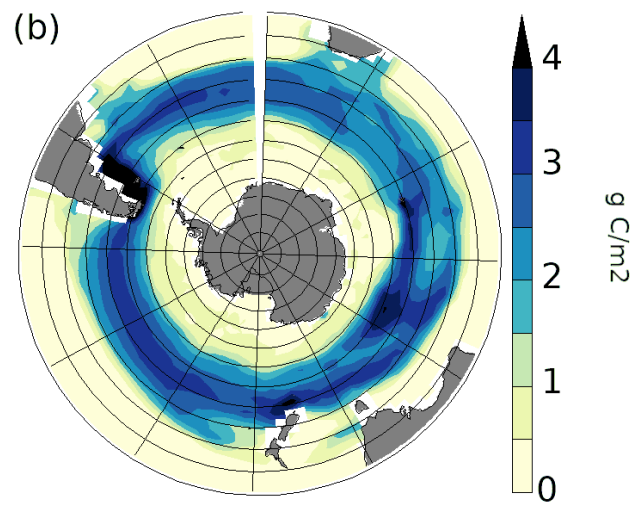

NPP

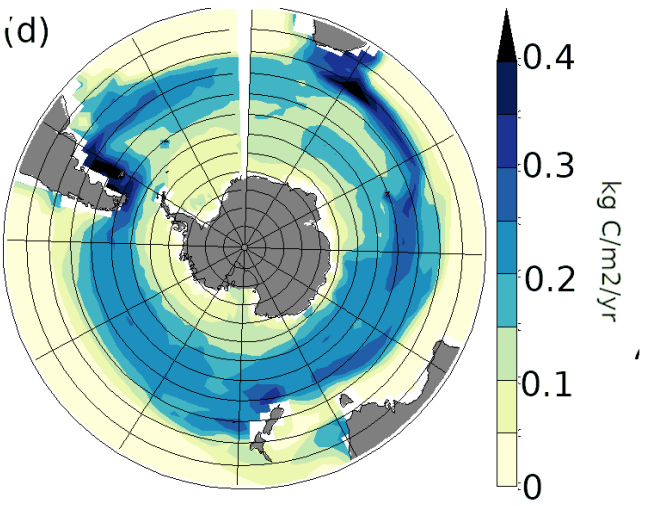

Figure 3. PI distribution of (a) depth integrated diatoms (in $\mathrm{gC} \mathrm{m}^{-2}$ ), (b) depth integrated coccolithophores (in $\mathrm{gC} \mathrm{m}^{-2}$ ), (c) export production at $177.5 \mathrm{~m}$ (in $\mathrm{kgC} \mathrm{m}^{-2} \mathrm{yr}^{-1}$ ) and (d) depth integrated net primary productivity (in $\mathrm{kgC} \mathrm{m}^{-2} \mathrm{yr}^{-1}$ )

\subsection{Impact of LGM climate on Southern Ocean ecosystems}

In this section, we examine how glacial-interglacial changes in physical conditions, such as temperature, salinity and ocean circulation, impact Southern Ocean ecosystems. We therefore compare the LGM-clim simulation with the PI simulation. While diazotrophs and general phytoplankton are abundant in the subtropics, they are not present in the Southern Ocean. We therefore concentrate our analysis on the two major plankton functional types in polar regions, diatoms and coccolithophores (Figure $3 \mathrm{a}$ and b).

Due to stronger deep-ocean ventilation in the Weddell and Ross Sea regions in the LGM-clim simulation, surface nutrient concentrations are higher everywhere in the Southern Ocean, except in the Pacific sector, where stratification increases (Figure 2c-f). This leads to higher diatom abundance over most of the Southern Ocean south of $40^{\circ} \mathrm{S}$ (Figure 4a). Regional changes in diatom abundance closely mirror regional nutrient changes (Figure 2c,d and Figure 4a). However, there are also regions with a significant decline in diatoms that are not directly linked to nutrient changes. For example, it has been suggested that the extension of ice-shelves around Antarctica and the equatorward expansion of sea-ice during the LGM led to a decrease in diatom abundance around the Antarctic coastline, and an increase north of the sea ice edge (Crosta et al., 1998; Gersonde et al., 2005; Nair et al., 2015). The simulated decrease in LGM diatom abundances in the 
Ross and Weddell Seas due to light limitation under sea-ice, despite increased nutrient concentrations, is consistent with this paleo-data evidence, as is the simulated $19 \%$ and $26 \%$ increase in diatom abundances north of the winter sea-ice edge in the South Atlantic $\left(40^{\circ} \mathrm{S}-50^{\circ} \mathrm{S}\right)$ and the South Pacific, respectively. However, high macro and micro nutrient concentrations aid diatom growth in the seasonal sea-ice region and increase the diatom abundance by $9 \%$ in the Indian Ocean and by $31 \%$ in the South Atlantic sector $\left(55^{\circ} \mathrm{W}: 0^{\circ} \mathrm{E} ; 50^{\circ} \mathrm{S}: 60^{\circ} \mathrm{S}\right)$.

While changes in diatom abundance are mainly driven by changes in the availability of nutrients (and therefore circulation changes) and the presence or absence of seaice, changes in coccolithophores are driven by the dynamic competition with diatoms. For example, the increase in diatom abundance north of the summer sea-ice extent $\left(52^{\circ} \mathrm{S}-\right.$ $65^{\circ} \mathrm{S}$ ) in the LGM-clim simulation is associated with a decrease in coccolithophores (by $-21 \%$ ) (Figure 4b). Diatoms are prescribed a faster growth rate, which is an advantage in nutrient-rich environments and/or regions with short growing seasons such as the Southern Ocean. Fast utilisation of nutrients by diatoms causes a decline in the coccolithophore population that might not otherwise have occurred. However, in the Pacific sector, where ventilation depth and nutrient availability decrease in the LGM-clim simulation, diatom abundance also decreases, while coccolithophores show a slight increase. Only in regions such as in the southwestern Atlantic at $40^{\circ} \mathrm{S}-54^{\circ} \mathrm{S}$, where diatoms are not as competitive, coccolithophores can take full advantage of higher Fe availability and increase by $\sim 11 \%$ in the LGM-clim simulation (Figure 3a, b and Figure 4b). Overall, diatoms outcompete coccolithophores in most of the Southern Ocean under LGM conditions.

While diatoms increase by $31 \%$ in the South Atlantic south of the winter sea-ice edge $\left(55^{\circ} \mathrm{W}: 0^{\circ} \mathrm{E} ; 50^{\circ} \mathrm{S}: 60^{\circ} \mathrm{S}\right)$ and by $9 \%$ within the sea-ice zone in the Indian Ocean, coccolithophores decline by $21 \%$, thus leading to a $2 \%$ decrease in NPP within the seasonal sea-ice zone. However, as diatoms in colder environments are more efficient at exporting carbon than coccolithophores in warmer environments, EP increases by $7.6 \%$ in this region. Overall, NPP decreases by $11 \%$ in the Southern Ocean $\left(30^{\circ} \mathrm{S}: 90^{\circ} \mathrm{S}\right)$ with a $7.4 \%$ decrease north of the LGM winter sea-ice edge, and a $15 \%$ decrease south of it (Table 2 ). The integrated EP at $177.5 \mathrm{~m}$ increases by $4.7 \%$ north of the LGM winter sea-ice edge, while it decreases by $7 \%$ south of it $\left(30^{\circ} \mathrm{S}-50^{\circ} \mathrm{S}\right)$ (Table 2$)$. The overall EP decreases by $2.4 \%$ in the Southern Ocean $\left(30^{\circ} \mathrm{S}: 90^{\circ} \mathrm{S}\right)$.

We compare the simulated LGM-PI surface diatom abundance anomalies and EP at $177.5 \mathrm{~m}$ anomalies against the proxy-based LGM-Holocene opal flux and EP index anomalies of Kohfeld et al. (2013) (Figure 4a and c). In agreement with proxy data, diatom abundance and EP are higher north of the winter sea-ice edge in the South Atlantic. In the other sectors of the Southern Ocean the agreement between model and data is low north of the winter sea-ice edge, $42 \%$ and $51 \%$ for diatom and EP, respectively, based on counting fit or misfit at proxy locations. This is due to both a lack of a consistent signal in the proxy records (e.g. in the Pacific sector) and a complex pattern of simulated anomalies (e.g. eastern part of the Indian sector). In broad agreement with proxy data, diatom abundance is lower south of the winter sea-ice edge in the Pacific and eastern Indian sectors of the Southern Ocean. This translates into lower EP in these regions. However, contrary to the data compilation, higher diatom abundance and EP are simulated in the seasonally ice-free Atlantic and western Indian sectors of the Southern Ocean, as well as north of the Ross Sea.

As mentioned in Section 3.2, the increase in diatom abundances in the Atlantic sector of the Southern Ocean is due to increased nutrients resulting from enhanced bottom water formation in the Weddell Sea. While this higher diatom abundance within the seasonal sea-ice zone of the South Atlantic is at odds with the proxy compilation of Kohfeld et al. (2013), Abelmann et al. (2006) show that the seasonal sea-ice zone in the south Atlantic could have hosted blooms of fast growing diatoms due to higher iron concentrations. This could have been sustained by a deeper winter mixed layer at the LGM, 


\section{LGM-clim - PI}
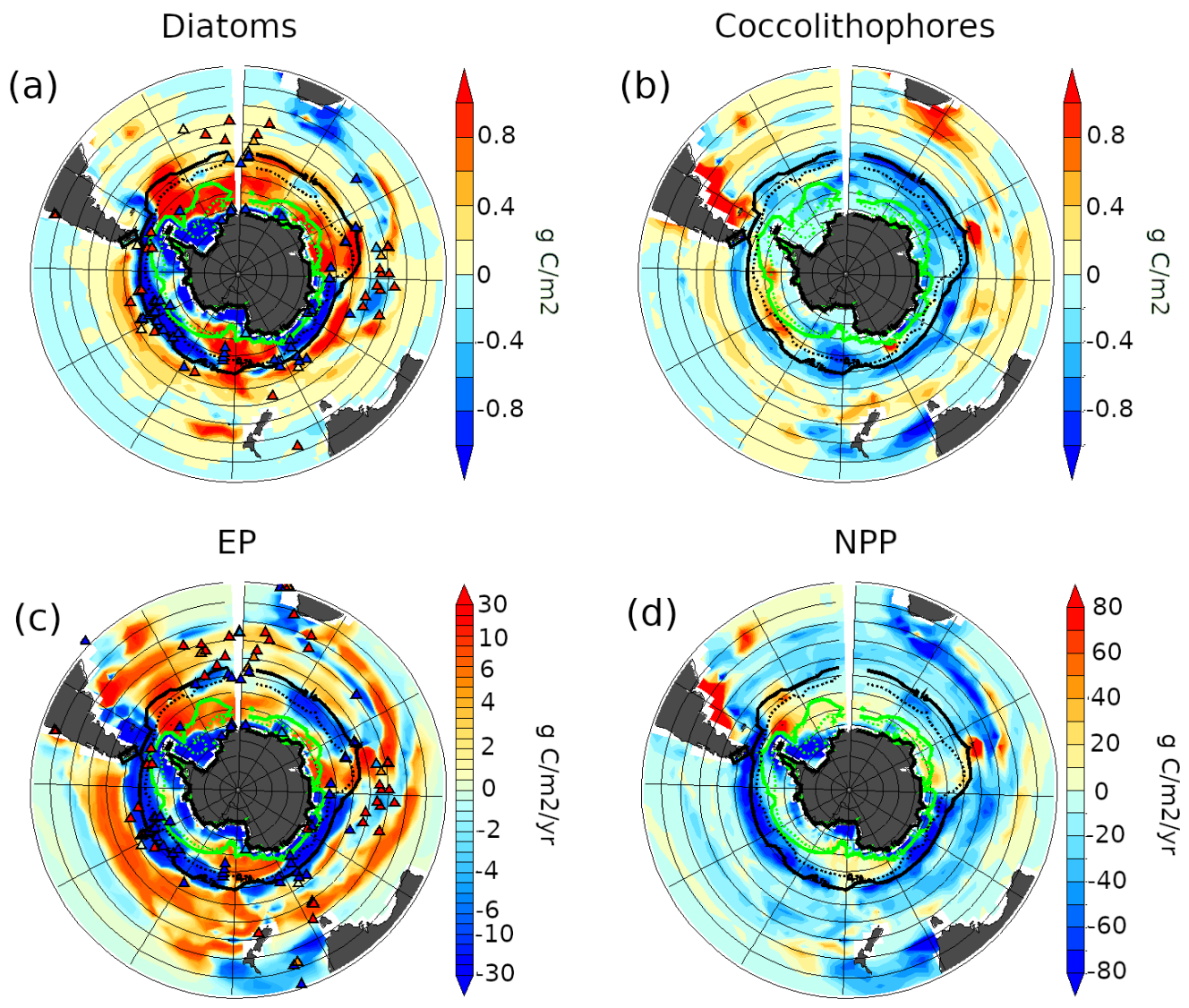

Figure 4. LGM-clim to PI anomalies of annual mean (a) depth integrated diatom abundance (in $\mathrm{g} \mathrm{C} \mathrm{m}^{-2}$ ) with LGM-Holocene opal flux proxies, (b) depth integrated coccolithophore abundance (in $\mathrm{g} \mathrm{C} \mathrm{m}^{-2}$ ), (c) export production at $177.5 \mathrm{~m}$ (in $\mathrm{g} \mathrm{C} \mathrm{m}^{-2} \mathrm{yr}^{-1}$ ) with LGM-Holocene export production index based on proxies, and (d) depth integrated NPP (in $\mathrm{g} \mathrm{C} \mathrm{m}^{-2} \mathrm{yr}^{-1}$ ). Please note that the intervals are non linear in subpanel (c). Qualitative changes in opal flux (a) and export production (c) as estimated from proxy records (Kohfeld et al., 2013) are shown with significantly higher values represented by dark orange triangles, slightly higher values by light orange triangles, significantly lower values by dark blue triangles and slightly lower values by light blue triangles. 


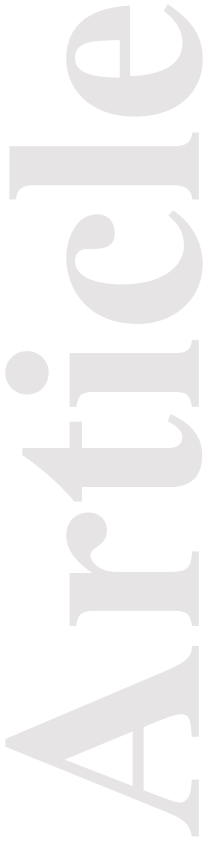

\section{Coccolithophores}

(a)

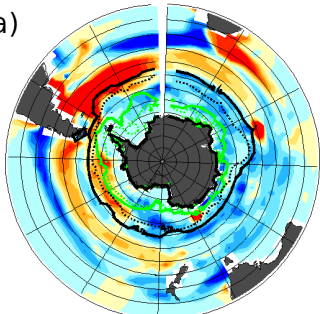

(d)

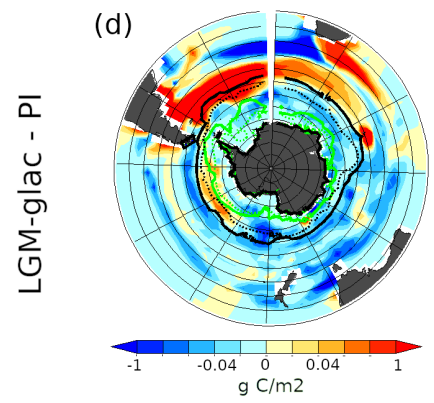
are non linear in subpanels $(\mathrm{c}, \mathrm{f})$
Diatoms

(b)

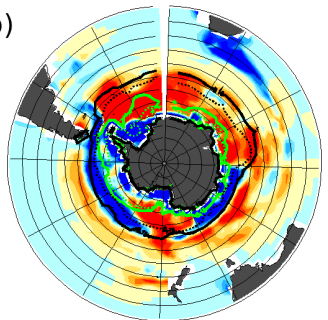

(e)

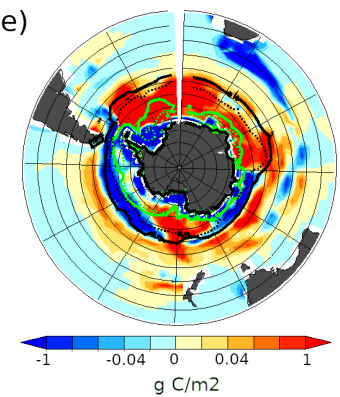

EP

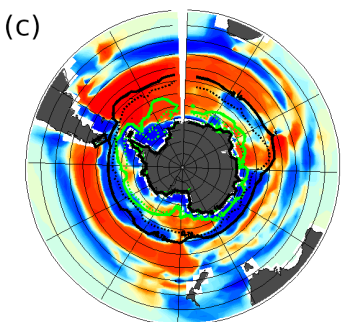

(f)

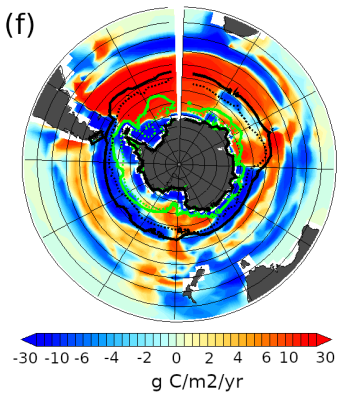

Figure 5. Annual mean anomalies for LGM-lamb (top row) and LGM-glac (bottom row) minus PI; (a,d) depth integrated coccolithophores (in $\mathrm{gC} \mathrm{m}^{-2}$ ), (b, e) depth integrated diatoms (in $\mathrm{gC} \mathrm{m}^{-2}$ ) and (c, f) export production at $177.5 \mathrm{~m}\left(\right.$ in $\left.\mathrm{gC} \mathrm{m}^{-2} \mathrm{yr}^{-1}\right)$. Please note that the intervals

which would have led to surface nutrient refuelling (Abelmann et al., 2015), as simulated here.

\subsection{Impact of glacial aeolian iron and silica fluxes on the Southern Ocean ecosystems}

In this section, we analyse the impact of the combined effect of climate change and LGM aeolian dust supply on the simulated ecosystems during the LGM. We force the model with an LGM iron dust deposition flux based on Mahowald et al. (2006) (Figure 1a, Fe-BASE-LGM, experiment LGM-BASE-ref) that is characterised by a $83 \%$ increase in dust compared to PI in a small area at $\sim 60^{\circ} \mathrm{S}$ extending from South America to $20^{\circ} \mathrm{W}$ in the South Atlantic. Interestingly, the aeolian dust input decreases by $96 \%$ southeast of Australia, and by $57 \%$ at $\sim 40^{\circ} \mathrm{S}$ in the South Atlantic compared to PI. While experiment LGM-BASE-ref is integrated with full glacial dust fluxes (Fe-BASE-LGM and SiBASE-LGM), the individual effects of iron and silica supply are studied in experiments LGM-BASE-HFe and LGM-BASE-HSi, respectively. We find that, despite a $50 \%$ global increase in iron dust in LGM-BASE-HFe (Table 1), and a $42 \%$ increase in silica dust in LGM-BASE-HSi, iron and silica deposition decreases over most of the Southern Ocean, except for the southwest Atlantic (Figure 1a and d). We do not see any significant changes in global NPP (Table 2) and ecosystem distribution between LGM-BASE-HFe (Figure S3) and LGM-BASE-HSi (not shown) compared to LGM-clim. LGM-BASE-ref results are also similar to the results of LGM-BASE-HFe (Table 2), showing that there are no non-linear effects. We therefore do not discuss LGM-BASE-HFe, LGM-BASE-HSi and LGM-BASE-ref further. We limit this study to iron sensitivity tests only and leave the silica sensitivities for future study.

Since the Southern Ocean is an iron-limited area (Assmy et al., 2013), we focus on two additional iron sensitivity experiments (LGM-lamb and LGM-glac, Table 1, Figure 1b 
and c) based on Lambert et al. (2015) and Ohgaito et al. (2018) with a 78\% and $84 \%$ increase in aeolian iron-deposition in the Southern Ocean respectively. First, we compare LGM-lamb with PI (Figure 5, upper panels). Overall, the regional patterns of changes in diatoms are very similar to the LGM-clim simulation, and are therefore still circulation driven, but the magnitude of change has increased. An iron enrichment of Southern Ocean waters leads to an additional increase in coccolithophores north of the winter sea-ice edge and an additional increase in diatoms south of the winter sea-ice edge over the Atlantic sector (compare Figure 5a, b with Figure 4b, a). Coccolithophores thus increase by $43 \%$ in the southwest Atlantic $\left(65^{\circ} \mathrm{W}: 20^{\circ} \mathrm{W}\right.$ and $\left.40^{\circ} \mathrm{S}: 50^{\circ} \mathrm{S}\right)$, leading to a $23 \%$ NPP increase in that region compared to PI. Diatoms increase by $52 \%$ and $13 \%$ within the seasonal sea-ice zone $\left(50^{\circ} \mathrm{S}: 60^{\circ} \mathrm{S}\right)$ of the South Atlantic and the Indian Ocean, respectively, further increasing EP by $60 \%$ in this sector (Figure $5 \mathrm{c}$ ) compared to PI. Diatoms use the high iron supply more efficiently because of the prescribed higher growth rate parameter and higher half saturation constant for iron uptake in the model (Section 2.1). North of $50^{\circ} \mathrm{S}$, the increase in coccolithophore biomass seen in LGM-clim is enhanced by the larger iron dust flux. Interestingly, NPP further decreases north of $50^{\circ} \mathrm{S}$, while it slightly increases south of $50^{\circ} \mathrm{S}$ compared to LGM-clim (Table 2).

We next test the impact of a higher iron input by including glaciogenic dust sources (Figure 1c) in our LGM-glac experiment. Surprisingly, only small differences are simulated between LGM-glac and LGM-lamb (Figure 5): between $50^{\circ} \mathrm{S}$ and $60^{\circ} \mathrm{S}$ EP in the South Atlantic shows an additional increase of $7 \%$ in LGM-glac (compared to LGM-lamb) while NPP increases by $3 \%$ near Argentina. It is interesting to note that although the addition of aeolian iron to the ocean leads to an increase in phytoplankton biomass, the spatial pattern of change in plankton distributions are similar in all of these experiments. For example, the Fe-lamb-LGM iron flux shows higher dust input into the South Pacific compared to the other iron fluxes (Figure 1a-c). This higher aeolian input leads to higher coccolithophore abundance (also slightly higher diatoms), and thus higher NPP (not shown) and EP (Figure 5), between $45^{\circ} \mathrm{S}$ and $50^{\circ} \mathrm{S}$ in the South Pacific in the LGM-lamb experiment, while keeping the ecosystem distribution pattern similar in all three experiments. As a result, the averaged EP increases by $\sim 1.8 \%$ (Table 2) north and south of the winter sea-ice edge $\left(50^{\circ} \mathrm{S}\right)$ in both LGM-lamb and LGM-glac compared to PI. Overall, NPP decreases by $13-14 \%$ north of $50^{\circ} \mathrm{S}$ and by $6 \%$ south of $50^{\circ} \mathrm{S}$ in both LGM-lamb and LGM-glac compared to PI (Table 2).

By mostly modulating the magnitude of the anomalies and not significantly changing the spatial patterns, LGM-lamb and LGM-glac do not substantially improve the modeldata comparison. The increase in diatom abundance and EP in the South Atlantic simulated in all our LGM simulations are not supported by paleo-proxy records. Since this increase seems to be driven by enhanced bottom water formation in the Weddell Sea, we perform an additional experiment in which we reduce bottom water formation in the Weddell Sea (LGM-W), and thus analyse the impact of a more stratified glacial Southern Ocean on marine ecosystems.

\subsection{Impact of weaker Weddell Sea ventilation on ecosystems}

Earlier research has suggested a more stratified Southern Ocean during the LGM compared to PI, which would have enhanced the sequestration of glacial carbon into the deep ocean (Francois et al., 1997; Sigman \& Boyle, 2001; Skinner et al., 2010; Menviel et al., 2017; Huang et al., 2020; Sigman et al., 2020). Changes in stratification in the Southern Ocean are therefore studied in our last sensitivity experiment (LGM-W), where we suppress bottom water formation in the Weddell Sea by adding a sustained freshwater flux of $0.1 \mathrm{~Sv}$ into this region. We force this experiment with the same iron and silica forcing as LGM-lamb. The resulting changes in SST and ventilation depth are shown in Figure 6a and b. Simulation LGM-W is characterised by a reduction in ventilation in the Weddell Sea, as well as reduced ventilation and SSTs in the Indian Ocean and Pa- 

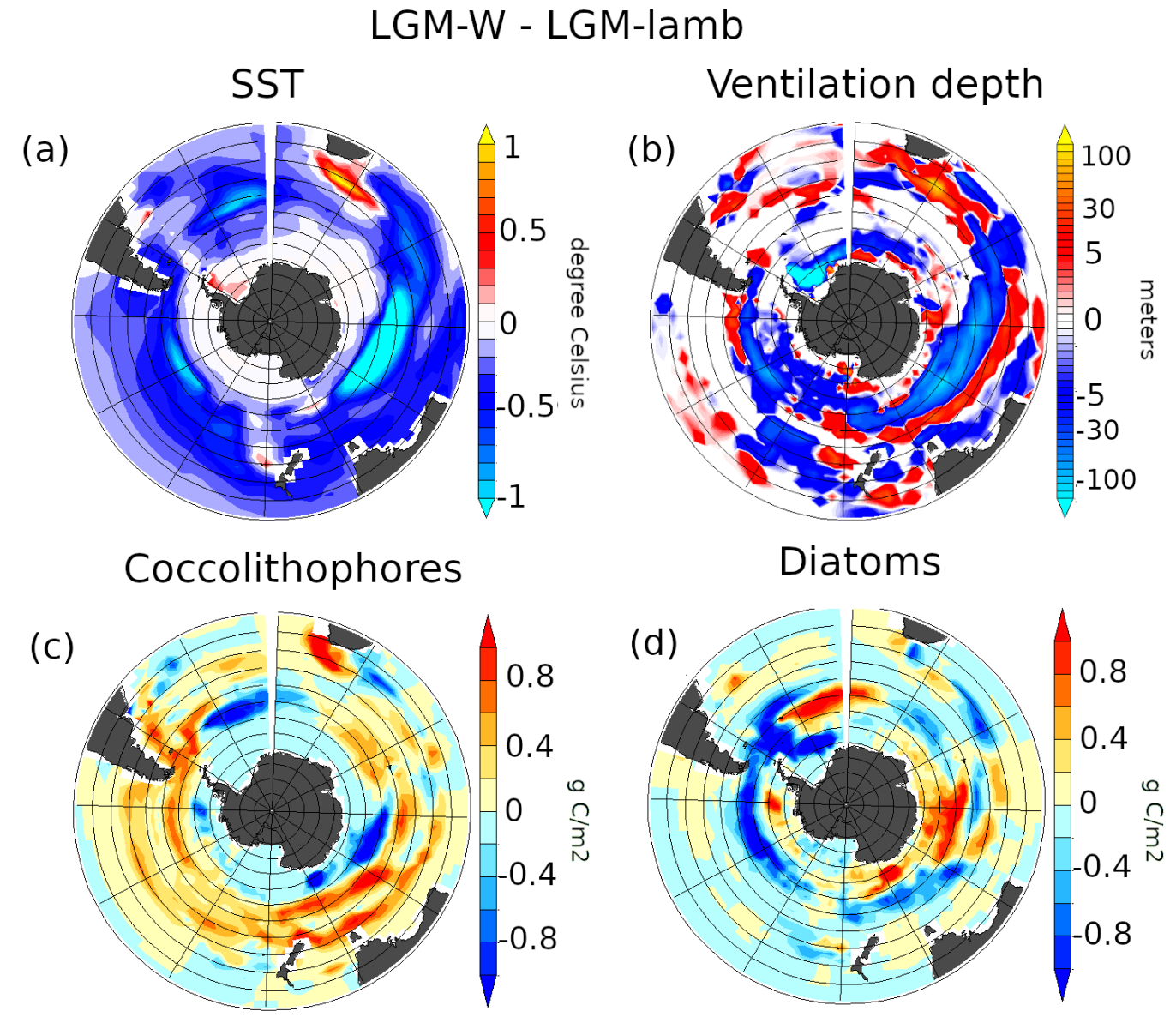

Figure 6. LGM-W to LGM-lamb anomalies of annual mean (a) sea surface temperatures $\left({ }^{\circ} \mathrm{C}\right),(\mathrm{b})$ ocean ventilation depth (meters), (c) depth integrated coccolithophores (in $\mathrm{gC} \mathrm{m}^{-2}$ ) and (d) depth integrated diatoms (in $\mathrm{gC} \mathrm{m}^{-2}$ ). Please note that the intervals are non linear in subpanel (b). 


\section{LGM-W - PI}

\section{Diatoms}

(a)

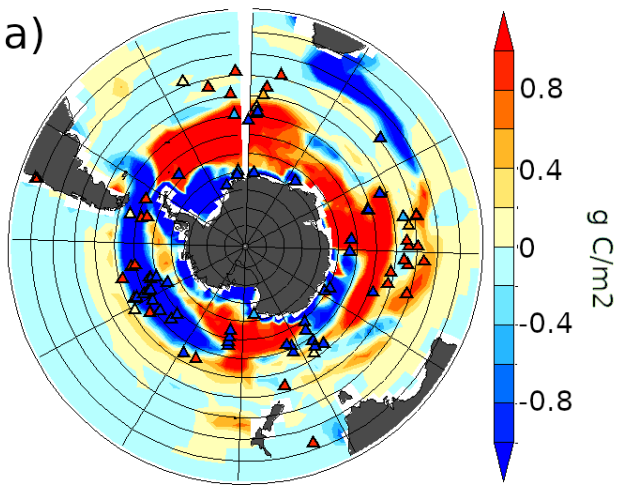

EP

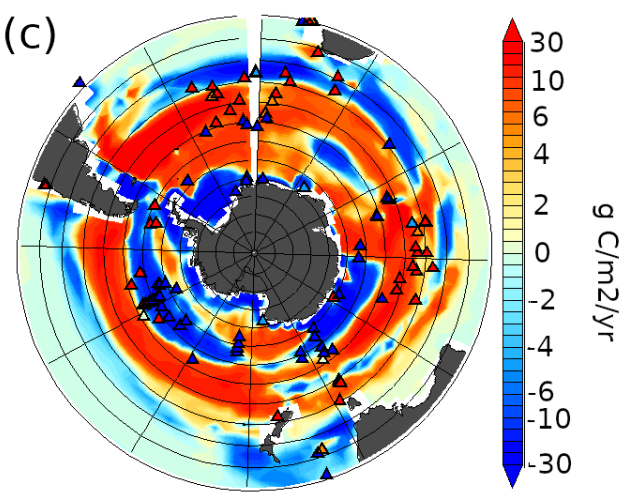

Coccolithophores

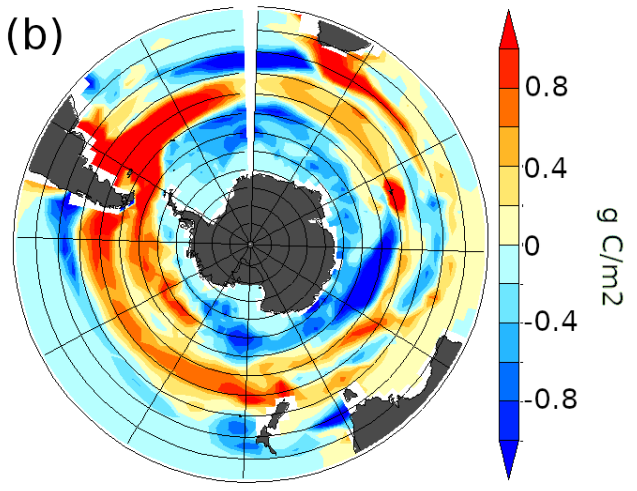

NPP

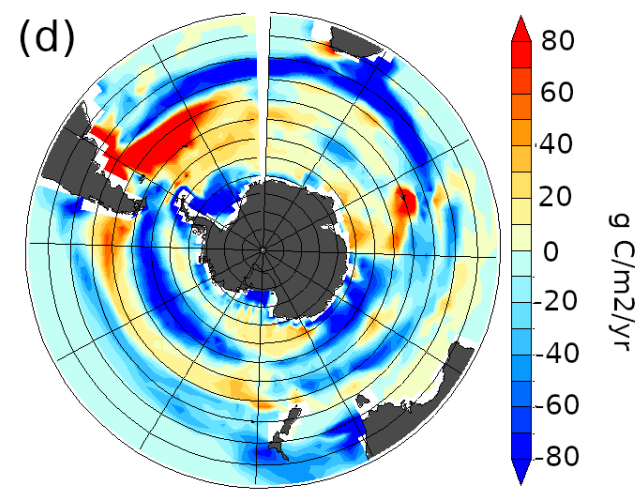

Figure 7. LGM-W to PI anomalies in annual mean (a) depth-integrated diatoms (in g C $\mathrm{m}^{-2}$ ) with LGM-Holocene opal flux proxies, (b) depth-integrated coccolithophores (in $\mathrm{g} \mathrm{C} \mathrm{m}^{-2}$ ), (c) export production at $177.5 \mathrm{~m}$ (in $\mathrm{g} \mathrm{C} \mathrm{m}^{-2} \mathrm{yr}^{-1}$ ) with LGM-Holocene export production index based on proxies, and (d) depth-integrated NPP (in $\mathrm{g} \mathrm{C} \mathrm{m}^{-2} \mathrm{yr}^{-1}$ ). Please note that the intervals are non linear in (c); proxies are from Kohfeld et al. (2013) and represent significantly higher (dark orange triangles), slightly higher (light orange triangles), significantly lower (dark blue triangles) and slightly lower (light blue triangles) changes.

cific sectors at $\sim 55^{\circ} \mathrm{S}$, while there is an increase south of the African continent. In this simulation, increased stratification in the Weddell Sea leads to reductions in diatom abundance in this region and downstream of this region. The large decrease in SST in the South Atlantic and South Indian sectors leads to a sharp decrease in coccolitophore abundance. As the growing season is shorter due to lower SSTs and sea-ice expansion (not shown), diatoms outcompete coccolithophores due to their higher growth rate (Figure $6 \mathrm{c}$ and $\mathrm{d}$ ).

Reducing ventilation in the Weddell Sea leads to an increase in both diatom abundance and $\mathrm{EP}$ in the eastern Indian Ocean and between $52^{\circ} \mathrm{S}-65^{\circ} \mathrm{S}$ in the South Atlantic Ocean. Overall, Southern Ocean EP increases by $4.4 \%$ in this experiment with a large $\sim 8 \%$ increase north of the LGM winter sea-ice edge compared to PI (Table 2). Figure 7 shows that the model data consistency is higher in this experiment (LGM-W), especially in the Indian Ocean sector. This improves our model data comparison to $61 \%$ in the Southern Ocean. 
Table 2. Integrated biogeochemical properties. The values in bracket are percentage anomalies from PI.

\begin{tabular}{|c|c|c|c|c|c|c|c|c|}
\hline Experiments & $\begin{array}{l}\text { Global NPP } \\
\left(\text { Pg C yr }^{-1}\right)\end{array}$ & $\begin{array}{l}\mathrm{SO} \mathrm{NPP} \\
\left(30^{\circ} \mathrm{S}: 90^{\circ} \mathrm{S}\right. \\
\left.\mathrm{Pg} \mathrm{C} \mathrm{yr}^{-1}\right)\end{array}$ & $\begin{array}{l}\text { SO NPP } \\
\text { north of } \\
\text { winter sea- } \\
\text { ice edge } \\
\left(30^{\circ} \mathrm{S}: 50^{\circ} \mathrm{S},\right. \\
\left.\mathrm{Pg} \mathrm{C} \mathrm{yr}^{-1}\right)\end{array}$ & $\begin{array}{l}\text { SO NPP } \\
\text { south of } \\
\text { winter sea- } \\
\text { ice edge } \\
\left(50^{\circ} \mathrm{S}: 90^{\circ} \mathrm{S}\right. \\
\mathrm{Pg} \mathrm{C} \mathrm{yr}\end{array}$ & $\begin{array}{l}\text { Global EP } \\
\left(\text { Pg C yr }^{-1}\right)\end{array}$ & $\begin{array}{l}\text { SO EP } \\
\left(30^{\circ} \mathrm{S}: 90^{\circ} \mathrm{S}\right. \\
\left.\mathrm{Pg} \mathrm{C} \mathrm{yr}^{-1}\right)\end{array}$ & $\begin{array}{l}\text { SO EP north } \\
\text { of winter } \\
\text { sea-ice edge } \\
\left(30^{\circ} \mathrm{S}: 50^{\circ} \mathrm{S}\right. \\
\left.\mathrm{Pg} \mathrm{yr}^{-1}\right)\end{array}$ & $\begin{array}{l}\text { SO EP south } \\
\text { of winter } \\
\text { sea-ice edge } \\
\left(50^{\circ} \mathrm{S}: 90^{\circ} \mathrm{S},\right. \\
\mathrm{Pg} \mathrm{C} \mathrm{yr}-1)\end{array}$ \\
\hline PI & 47.45 & 14.63 & 7.62 & 7 & 7.19 & 3.84 & 1.58 & 2.267 \\
\hline LGM-clim & $39.46(-16.8)$ & $13.02(-11)$ & $7.057(-7.4)$ & $5.96(-15)$ & $6.85(-4.7)$ & $3.75(-2.4)$ & $1.65(+4.7)$ & $2.10(-7)$ \\
\hline LGM-BASE-HFe & $39.37(-17)$ & $12.87(-12)$ & $6.97(-8.6)$ & $5.9(-15.7)$ & $6.88(-4.4)$ & $3.72(-3.3)$ & $1.63(+3.4)$ & $2.08(-8)$ \\
\hline LGM-BASE-HSi & $39.46(-16.8)$ & $13.02(-11)$ & $7.05(-7.3)$ & $5.96(-15)$ & $6.84(-4.8)$ & $3.75(-2.5)$ & $1.65(+4.7)$ & $2.09(-7.5)$ \\
\hline LGM-BASE-ref & $39.39(-17)$ & $12.88(-12)$ & $6.97(-8.5)$ & $5.90(-16)$ & $6.87(-4.5)$ & $3.72(-3.4)$ & $1.64(+3.5)$ & $2.08(-8)$ \\
\hline LGM-lamb & $38.34(-19)$ & $13.18(-10)$ & $6.6(-13)$ & $6.58(-6)$ & $6.94(-3.5)$ & $3.92(+1.9)$ & $1.61(+1.9)$ & $2.3(+1.8)$ \\
\hline LGM-glac & $38.22(-19)$ & $13.07(-10.6)$ & $6.51(-14)$ & $6.55(-6)$ & $6.90(-4)$ & $3.91(+1.7)$ & $1.6(+1.8)$ & $2.32(+2.2)$ \\
\hline LGM-W & $37.02(-22)$ & $13.36(-8.7)$ & $6.93(-9)$ & $6.43(-8.2)$ & $6.894(-4.1)$ & $4.01(+4.4)$ & $1.708(+8)$ & $2.31(+1.8)$ \\
\hline
\end{tabular}

\section{Discussion}

Our simulations suggest that without changes in aeolian iron input there is a $16.8 \%$ decrease in global NPP and a $4.7 \%$ decrease in global EP (Table 2) during the LGM (LGMclim experiment) compared to PI. In the Southern Ocean, the simulated EP decreases by $2.4 \%$ while NPP decreases by $11 \%$. These results are consistent with previous studies. Due to LGM boundary conditions Yamamoto et al. (2019) simulate a 7\% and 4\% decrease in global and Southern Ocean EP, respectively. Muglia et al. (2017) suggest larger changes with a $13 \%$ and $26 \%$ decrease in global and SO EP, respectively. .

Due to larger sea-ice extent and therefore a shorter growing season, as well as lower SSTs at the LGM, the abundance of coccolithophores and NPP decrease in the Southern Ocean from $5^{\circ}$ north of the simulated LGM winter sea-ice edge to the Antarctic continent. This is also the case for diatoms and EP, but enhanced deep-ocean convection in our LGM simulation leads to a regional increase in these quantities in the seasonal sea-ice zone of the Atlantic and Indian sectors. Southern Ocean EP increases by $4.7 \%$ north of the LGM austral winter sea-ice, while it decreases by $7 \%$ south of the winter sea-ice edge compared to PI. This increase of EP north of winter sea-ice and decrease south of the sea-ice is somewhat consistent with previous modelling results (Menviel et al., 2012, 2017; Yamamoto et al., 2019).

The proxy compilation suggests a regional dipole in EP during the LGM, with an increase in EP north of the sea-ice edge and a decrease south of it (Kohfeld et al., 2005, 2013). Inaccuracies in the simulated sea-ice extent can therefore lead to potential errors in ecosystem response in climate models. While the increase in diatoms and EP in the LGM-clim simulation north of the winter sea-ice edge in the South Atlantic, and the decrease south of the winter sea-ice edge in the South Pacific and Indian sectors are fairly consistent with the proxy records, the increase in diatoms and EP due to increased ventilation south of the winter sea-ice edge in the South Atlantic is not (Kohfeld et al., 2013). However, additional records from that region are needed, as previous studies suggest that there could have been an increase in diatoms in that region, that remained undetected in sediment opal fluxes (Abelmann et al., 2006, 2015).

It has been previously hypothesised that enhanced aeolian iron input into HNLC regions during the LGM could have increased NPP and EP in these regions (Martin, 1990). However, there are significant uncertainties associated with the regional magnitude of dust fluxes during the LGM, particularly in the Southern Ocean (Mahowald et al., 2006; Albani et al., 2014; Lamy et al., 2014; Lambert et al., 2015; Albani et al., 2016; Ohgaito et al., 2018; Courtillat et al., 2020). Comparing these different estimates with lithogenic fluxes from marine sediment cores suggests that the best agreement is obtained for the LGM-lamb dust mask (Lambert et al., 2015), due to the increase in dust deposition in the south Pacific region. It is interesting to note that, in agreement with previous re- 
sults (Schmittner \& Somes, 2016), the simulated global NPP is 16-22\% lower in our LGM simulations than in our PI run, regardless of the large range of changes in aeolian iron and silica fluxes included in our study.

Despite large differences in the patterns and magnitude of dust fluxes tested here, the pattern of the simulated ecosystem anomalies are similar in the Southern Ocean. Regional changes are mostly driven by changes in oceanic circulation, SST and sea-ice, while the magnitude (and sign) of the anomalies is modulated by the iron input (Figure 5). For example, the glacial iron input into the Southern Ocean in the LGM-lamb experiment intensifies the coccolithophore and diatom abundance by $43-52 \%$ respectively, in some regions (near Argentina, South Atlantic and Indian Ocean between $50^{\circ} \mathrm{S}: 60^{\circ} \mathrm{S}$ ) compared to PI. This further increases EP by $46 \%$ and NPP by $21 \%$ in these regions compared to the LGM experiment without additional iron input (LGM-clim). The additional iron input in the Pacific sector of the Southern Ocean in LGM-lamb leads to a $15 \%$ increase in EP compared to LGM-clim in this region. Therefore, the overall Southern Ocean EP increases in both LGM-lamb and LGM-glac, and even exceeds the Southern Ocean EP simulated in PI by 1.8\%, while Yamamoto et al. (2019) and Muglia et al. (2017) show a decline of $2 \%$ and $18 \%$ compared to PI, respectively.

The fact that physical processes control the pattern of EP anomalies between LGM and PI, and that additional iron input modulates the magnitude of the anomalies, is consistent with Menviel et al. (2012); Yamamoto et al. (2019), but does not seem to be the case in the study by Muglia et al. (2017), which shows a decline in EP with dust. It is also interesting to note that the location of the EP "dipole" pattern due to the sea-ice edge varies in different studies, from an increase north of the annual mean sea-ice edge (Menviel et al., 2012), to an increase everywhere north of the summer sea-ice edge (Yamamoto et al., 2019). In addition, in order to simulate a significant increase in Southern Ocean EP (13 to $24 \%$ compared to PI), previous studies had to force their model with a 10 -fold increase in aeolian iron deposition (Muglia et al., 2017) or increase the solubility of iron to $3-10 \%$ (Yamamoto et al., 2019).

$\delta^{15} \mathrm{~N}$ records suggest a higher consumption of nitrate south of the polar front associated with reduced primary production, indicating an increase in stratification in the Antarctic zone during glacial times (Francois et al., 1997; Jaccard et al., 2013; Sigman et al., 2020). This is investigated in our LGM-W experiment where weakening the bottom water formation in the Weddell Sea in our LGM simulation significantly impacts the Southern Ocean circulation, SSTs, and sea-ice cover. As a result, the pattern of ecosystem changes is different from the other experiments. Due to colder conditions and an associated shorter growing season, diatom abundance increases in the Indian ocean in the seasonal sea-ice zone, thus leading to an increase in EP in that region, and improving the model-data agreement to $61 \%$. Southern Ocean EP increases by $4.4 \%$ in this experiment compared to PI.

The total EP to NPP efficiency in the Southern Ocean is higher in all our LGM experiments compared to PI, and highest in the simulation using the Lambert et al. (2015) iron dust flux with weaker Weddell Sea bottom water formation (LGM-W). This is due to the combined effect of an overall dominance of diatoms and lower SSTs.

As with any modelling study, there are limitations related to model performance, model structure and experimental set up. In this study, we present results using the UVic ESCM which has a sophisticated ecosystem model and includes an ocean general circulation model, and a dynamic-thermodynamic sea-ice model. However, the atmospheric model is an energy moisture balance model. We therefore did not take changes in winds and wind stress into account in this study, and thus potential changes in upwelling strength. Southern Ocean aeolian silica input decreases in our set of experiments during the LGM compared to PI, and did not significantly impact ecosystems, we therefore leave the testing of the impact of large changes in aeolian Si supply on ecosystems for future research. 
Our results show that ecosystem response is highly dependent on light availability and nutrient availability during the short growth season in the Southern Ocean; better constraints on seasonal sea-ice cover, and oceanic circulation at the LGM are therefore needed. Additional paleo-proxy records are also needed to better constrain glacial changes in diatom abundance in the seasonal sea-ice zone.

\section{Conclusion}

We investigate changes in ecosystems, marine primary production and carbon export in the Southern Ocean between the LGM and the PI using an Earth system model of intermediate complexity, which includes a newly developed ecosystem model. We find that south of $50^{\circ} \mathrm{S}$, changes in diatoms and coccolithophores are driven by changes in nutrients and SSTs, with diatoms having an advantage over coccolithophores in shorter growing seasons. Greater sea-ice cover and reduced SSTs lead to a decrease in NPP and EP near the Antarctic coast south of the winter sea-ice edge, while an increase in nutrient supply increases EP in some regions north of the LGM winter sea-ice edge. Our results suggest that the regional distribution of phytoplankton anomalies is determined by physical ocean changes such as SSTs, ventilation depth, and seasonal sea-ice extent, while the magnitude and sign of the changes in EP and NPP is modulated by changes in iron input. Our simulations are forced with several published LGM dust flux reconstructions, which we re-evaluate based on a comparison with lithogenic dust flux anomalies. By forcing the model with the LGM aeolian iron fluxes based on Lambert et al. (2015), which show the best agreement with proxy data, and a stratified Weddell Sea, a $4.4 \%$ increase in Southern Ocean EP is simulated at the LGM compared to PI. This simulation, featuring enhanced aeolian iron input in the Pacific Ocean, weakened bottom water formation and enhanced stratification in the South Atlantic sector of the Southern Ocean, also shows the best agreement with proxy data of opal flux and EP anomalies. Interestingly, this simulation is also the most efficient in exporting carbon out of the mixed layer. While featuring the lowest global ocean NPP of all the LGM experiments, it also features the highest EP in the Southern Ocean. This is due to lower sea surface temperatures, higher nutrient availability, and a shift to higher diatom abundance.

\section{Acknowledgments}

Himadri Saini acknowledges funding from the University International Postgraduate Award scheme (UNSW). ZC and KJM acknowledge funding from the Australian Research Council grant DP180102357. LM acknowledges funding from the Australian Research Council grant FT180100606. All experiments were performed on the computational facility of NCI owned by the Australian National University through awards under the Merit Allocation Scheme, the Intersect allocation scheme, and the UNSW HPC at NCI Scheme. We thank Dr. Rumi Ohgaito for sharing the dust deposition data and Dr. Lise Missiaen for her help on an earlier version of the manuscript. Results from the modelling simulations are accessible at UNSW ResData through https://doi.org/10.26190/5f2b69ff95d8f. Lithogenic dust flux data is available through Francois et al. (1993); Frank et al. (1995, 2000); Kumar et al. (1995); Labeyrie et al. (1996); Dezileau et al. (2000); Chase et al. (2003); Anderson et al. (2009, 2014); Martínez-Garcia et al. (2009); Negre et al. (2010); Lippold et al. (2012); Jaccard et al. (2013); Lamy et al. (2014); Studer et al. (2015); Durand et al. (2017), and a compilation is available through https://doi.org/10.25959/6hsp-pt80.

A part of this compilation is also provided in the Supporting Information. The dust deposition data used for LGM and PI fluxes in Table 1 is available through Mahowald et al. (2006), for LGM-lamb through Lambert et al. (2015) and for LGM-glac is available through Ohgaito et al. (2018). The two dimensional field to calculate iron to dust and silica to dust ratio is available through Zhang et al. (2015). 


\section{References}

Abelmann, A., Gersonde, R., Cortese, G., Kuhn, G., \& Smetacek, V. (2006). Extensive phytoplankton blooms in the atlantic sector of the glacial southern ocean. Paleoceanography, 21 (1).

Abelmann, A., Gersonde, R., Knorr, G., Zhang, X., Chapligin, B., Maier, E., ... others (2015). The seasonal sea-ice zone in the glacial southern ocean as a carbon sink. Nature communications, 6(1), 1-13.

Albani, S., Mahowald, N., Murphy, L., Raiswell, R., Moore, J., Anderson, R., ... others (2016). Paleodust variability since the last glacial maximum and implications for iron inputs to the ocean. Geophysical Research Letters, 43(8), 3944-3954.

Albani, S., Mahowald, N., Perry, A., Scanza, R., Zender, C., Heavens, N., ... OttoBliesner, B. (2014). Improved dust representation in the community atmosphere model. Journal of Advances in Modeling Earth Systems, 6(3), 541-570.

Anderson, R., Ali, S., Bradtmiller, L., Nielsen, S., Fleisher, M., Anderson, B., \& Burckle, L. (2009). Wind-driven upwelling in the southern ocean and the deglacial rise in atmospheric co2. science, 323(5920), 1443-1448.

Anderson, R., Barker, S., Fleisher, M., Gersonde, R., Goldstein, S. L., Kuhn, G., ... Sachs, J. P. (2014). Biological response to millennial variability of dust and nutrient supply in the subantarctic south atlantic ocean. Philosophical Transactions of the Royal Society A: Mathematical, Physical and Engineering Sciences, 372(2019), 20130054.

Annan, J. D., \& Hargreaves, J. C. (2013). A new global reconstruction of temperature changes at the Last Glacial Maximum. Climate of the Past, 9(1), 367376. doi: 10.5194/cp-9-367-2013

Archer, D., \& Maier-Reimer, E. $\quad$ (1994). $\quad$ Effect of deep-sea sedimentary calcite preservation on atmospheric co2 concentration. Nature, 367(6460), 260-263.

Assmy, P., Smetacek, V., Montresor, M., Klaas, C., Henjes, J., Strass, V. H., ... Wolf-Gladrow, D. (2013). Thick-shelled, grazer-protected diatoms decouple ocean carbon and silicon cycles in the iron-limited Antarctic Circumpolar Current. Proceedings of the National Academy of Sciences of the United States of America, 110(51), 20633-20638. doi: 10.1073/pnas.1309345110

Baumert, H. Z., \& Petzoldt, T. (2008). The role of temperature, cellular quota and nutrient concentrations for photosynthesis, growth and light-dark acclimation in phytoplankton. Limnologica, 38(3-4), 313-326.

Benz, V., Esper, O., Gersonde, R., Lamy, F., \& Tiedemann, R. (2016). Last glacial maximum sea surface temperature and sea-ice extent in the pacific sector of the southern ocean. Quaternary Science Reviews, 146, 216-237.

Berger, A. L. (1978). Long-term variations of daily insolation and Quaternary climatic changes. (Vol. 35) (No. 12). ～doi: 10.1175/1520-0469(1978)035<2362: ltvodi $>2.0$. co; 2

Bopp, L., Kohfeld, K. E., Le Quéré, C., \& Aumont, O. $\quad$ (2003). Dust impact on marine biota and atmospheric co2 during glacial periods. Paleoceanography, $18(2)$.

Bradtmiller, L. I., Anderson, R. F., Fleisher, M. Q., \& Burckle, L. H. (2009). Comparing glacial and holocene opal fluxes in the pacific sector of the southern ocean. Paleoceanography, $24(2)$.

Charbit, S., Ritz, C., Philippon, G., Peyaud, V., \& Kageyama, M. (2007). Numerical reconstructions of the Northern Hemisphere ice sheets through the last glacialinterglacial cycle. Climate of the Past, 3(1), 15-37. doi: 10.5194/cp-3-15-2007

Chase, Z., Anderson, R. F., Fleisher, M. Q., \& Kubik, P. W. (2003). Accumulation of biogenic and lithogenic material in the pacific sector of the southern ocean during the past 40,000 years. Deep Sea Research Part II: Topical Studies in Oceanography, 50(3-4), 799-832. 
Collins, S., Rost, B., \& Rynearson, T. A. (2014). Evolutionary potential of marine phytoplankton under ocean acidification. Evolutionary Applications, 7(1), 140155. doi: $10.1111 /$ eva.12120

Courtillat, M., Hallenberger, M., Bassetti, M.-A., Aubert, D., Jeandel, C., Reuning, L., ... Saavedra-Pellitero, M. (2020). New record of dust input and provenance during glacial periods in western australia shelf (iodp expedition 356 , site u1461) from the middle to late pleistocene. Atmosphere, 11(11), 1251.

Crosta, X., Pichon, J.-J., \& Burckle, L. H. (1998). Application of modern analog technique to marine Antarctic and to reconstruct the modem We then use this approach to reconstruct presence in number of months per year during the last glacial maximum presence was greater than north of its the of modem sea. Paleoceanography, 13(3), 284-297.

DeVries, T., Primeau, F., \& Deutsch, C. (2012). The sequestration efficiency of the biological pump. Geophysical Research Letters, 39(13).

Dezileau, L., Bareille, G., Reyss, J., \& Lemoine, F. (2000). Evidence for strong sediment redistribution by bottom currents along the southeast indian ridge. Deep Sea Research Part I: Oceanographic Research Papers, 47(10), 1899-1936.

Ducklow, H. W., Steinberg, D. K., \& Buesseler, K. O. (2001). Upper ocean carbon export and the biological pump. Oceanography, 14(SPL.ISS. 4), 50-58. doi: 10 .5670 /oceanog.2001.06

Durand, A., Chase, Z., Noble, T. L., Bostock, H., Jaccard, S. L., Kitchener, P., ... others (2017). Export production in the new-zealand region since the last glacial maximum. Earth and planetary science letters, 469, 110-122.

Eby, M., Zickfeld, K., Montenegro, A., Archer, D., Meissner, K., \& Weaver, A. J. (2009). Lifetime of anthropogenic climate change: Millennial time scales of potential CO2 and surface temperature perturbations. Journal of Climate, 22(10), 2501-2511. doi: 10.1175/2008JCLI2554.1

Fanning, A. F., \& Weaver, A. J. (1996). An atmospheric energy-moisture balance model: Climatology, interpentadal climate change, and coupling to an ocean general circulation model. Journal of Geophysical Research: Atmospheres, 101(D10), 15111-15128. Retrieved from https://agupubs.onlinelibrary .wiley.com/doi/abs/10.1029/96JD01017 doi: 10.1029/96JD01017

Francois, R., Altabet, M. A., Yu, E.-F., Sigman, D. M., Bacon, M. P., Frank, M., ... Labeyrie, L. D. (1997). Contribution of southern ocean surface-water stratification to low atmospheric co 2 concentrations during the last glacial period. Nature, 389(6654), 929-935.

Francois, R., Bacon, M. P., Altabet, M. A., \& Labeyrie, L. D. Glacial/interglacial changes in sediment rain rate in the sw indian sector of subantarctic waters as recorded by $230 \mathrm{th}, 231 \mathrm{pa}, \mathrm{u}$, and $\delta 15 \mathrm{n}$. Paleoceanography, 8(5), 611-629.

Frank, M., Eisenhauer, A., Bonn, W. J., Walter, P., Grobe, H., Kubik, P. W., ... Mangini, A. (1995). Sediment redistribution versus paleoproductivity change: Weddell sea margin sediment stratigraphy and biogenic particle flux of the last 250,000 years deduced from 230thex, 10be and biogenic barium profiles. Earth and Planetary Science Letters, 136(3-4), 559-573.

Frank, M., Gersonde, R., van der Loeff, M. R., Bohrmann, G., Nürnberg, C. C., Kubik, P. W., ... Mangini, A. (2000). Similar glacial and interglacial export bioproductivity in the atlantic sector of the southern ocean: Multiproxy evidence and implications for glacial atmospheric co2. Paleoceanography, 15(6), 642-658.

Gersonde, R., Crosta, X., Abelmann, A., \& Armand, L. (2005). Sea-surface temperature and sea ice distribution of the Southern Ocean at the EPILOG Last Glacial Maximum - A circum-Antarctic view based on siliceous microfossil records. Quaternary Science Reviews, 24(7-9 SPEC. ISS.), 869-896. doi: 10.1016/j.quascirev.2004.07.015 
Graham, R. M., De Boer, A. M., van Sebille, E., Kohfeld, K. E., \& Schlosser, C. (2015). Inferring source regions and supply mechanisms of iron in the southern ocean from satellite chlorophyll data. Deep Sea Research Part I: Oceanographic Research Papers, 104, 9-25.

Green, R. A., Menviel, L., Meissner, K. J., \& Crosta, X. (2020). Evaluating seasonal sea-ice cover over the southern ocean from the last glacial maximum. Climate of the Past Discussions, 1-23.

Harrison, S. P., Kohfeld, K. E., Roelandt, C., \& Claquin, T. (2001). The role of dust in climate changes today, at the last glacial maximum and in the future. Earth-Science Reviews, 54(1-3), 43-80.

Herndl, G. J., \& Reinthaler, T. (2013). Microbial control of the dark end of the biological pump. Nature Geoscience, 6(9), 718-724. Retrieved from http://dx .doi.org/10.1038/ngeo1921 doi: 10.1038/ngeo1921

Hibler, W. D. (1979). A Dynamic Thermodynamic Sea Ice Model (Vol. 9) (No. 4). doi: 10.1175/1520-0485(1979)009〈0815:adtsim $\rangle 2.0 . c 0 ; 2$

Hopcroft, P. O., Valdes, P. J., Woodward, S., \& Joshi, M. M. $\quad$ (2015). $\quad$ Last glacial maximum radiative forcing from mineral dust aerosols in an Earth system model. Journal of Geophysical Research, 120(16), 8186-8205. doi: 10.1002/2015JD023742

Huang, H., Gutjahr, M., Eisenhauer, A., \& Kuhn, G. (2020). No detectable weddell sea antarctic bottom water export during the last and penultimate glacial maximum. Nature communications, 11(1), 1-10.

Hunke, E. C., \& Dukowicz, J. K. (1997). An elastic-viscous-plastic model for sea ice dynamics. Journal of Physical Oceanography(Hibler 1979), 18491867. Retrieved from http://journals.ametsoc.org/doi/pdf/10.1175/ 1520-0485 (1997) 027\{\\%\}3C1849\{\\%\}3AAEVPMF $\{\backslash \%\} 3 E 2.0 . C 0\{\backslash \%\} 3 B 2$

Jaccard, S. L., Hayes, C. T., Martinez-Garcia, A., Hodell, D. A., Anderson, R. F., Sigman, D. M., \& Haug, G. (2013). Two modes of change in southern ocean productivity over the past million years. Science, 339(6126), 1419-1423.

Jeltsch-Thömmes, A., Battaglia, G., Cartapanis, O., Jaccard, S. L., \& Joos, F. (2019). Low terrestrial carbon storage at the last glacial maximum: constraints from multi-proxy data. Climate of the Past, 15(2), 849-879.

Kalnay, E., Kanamitsu, M., Kistler, R., Collins, W., Deaven, D., Gandin, L., ... others (1996). The ncep/ncar 40-year reanalysis project. Bulletin of the American meteorological Society, 77(3), 437-472.

Khatiwala, S., Schmittner, A., \& Muglia, J. (2019). Air-sea disequilibrium enhances ocean carbon storage during glacial periods. Science advances, 5(6), eaaw 4981.

Kienast, S., Winckler, G., Lippold, J., Albani, S., \& Mahowald, N. (2016). Tracing dust input to the global ocean using thorium isotopes in marine sediments: Thoromap. Global Biogeochemical Cycles, 30(10), 1526-1541.

Klaas, C., \& Archer, D. E. (2002). Association of sinking organic matter with various types of mineral ballast in the deep sea: Implications for the rain ratio. Global Biogeochemical Cycles, 16(4), 63-1.

Kobayashi, H., Abe-Ouchi, A., \& Oka, A. (2015). Role of southern ocean stratification in glacial atmospheric co2 reduction evaluated by a three-dimensional ocean general circulation model. Paleoceanography, 30(9), 1202-1216.

Kohfeld, K. E., Graham, R., De Boer, A., Sime, L., Wolff, E., Le Quéré, C., \& Bopp, L. (2013). Southern hemisphere westerly wind changes during the last glacial maximum: paleo-data synthesis. Quaternary Science Reviews, 68, 76-95.

Kohfeld, K. E., \& Harrison, S. P. (2001). Dirtmap: the geological record of dust. Earth-Science Reviews, 54 (1-3), 81-114.

Kohfeld, K. E., Le Quéré, C., Harrison, S. P., \& Anderson, R. F. (2005). Role of marine biology in glacial-interglacial co2 cycles. Science, 308(5718), 74-78.

Kohfeld, K. E., \& Ridgwell, A. (2009). Glacial-interglacial variability in atmospheric 
co2. Surface Ocean/Lower Atmosphere Processes, Geophysical Monograph Series, 37 .

Kumar, N., Anderson, R., Mortlock, R., Froelich, P., Kubik, P., Dittrich-Hannen, B., \& Suter, M. (1995). Increased biological productivity and export production in the glacial southern ocean. Nature, 378(6558), 675-680.

Kvale, K., Keller, D. P., Koeve, W., Meissner, K. J., Somes, C., Yao, W., \& Oschlies, A. (2020). Explicit silicate cycling in the kiel marine biogeochemistry model, version 3 (kmbm3) embedded in the uvic escm version 2.9. Geoscientific Model Development Discussions, 1-46.

Kvale, K., Meissner, K., \& Keller, D. (2015b). Potential increasing dominance of heterotrophy in the global ocean. Environmental Research Letters, 10(7), 074009.

Kvale, K., Meissner, K., Keller, D., Eby, M., \& Schmittner, A. (2015a). Explicit planktic calcifiers in the university of victoria earth system climate model, version 2.9. Atmosphere-Ocean, 53(3), 332-350.

Kvale, K., Turner, K., Landolfi, A., \& Meissner, K. (2019). Phytoplankton calcifiers control nitrate cycling and the pace of transition in warming icehouse and cooling greenhouse climates. Biogeosciences (BG), 16(5), 1019-1034.

Labeyrie, L., Labracherie, M., Gorfti, N., Pichon, J. J., Vautravers, M., Arnold, M., ... others (1996). Hydrographic changes of the southern ocean (southeast indian sector) over the last $230 \mathrm{kyr}$. Paleoceanography, 11(1), 57-76.

Lambeck, K., Rouby, H., Purcell, A., Sun, Y., \& Sambridge, M. (2014). Sea level and global ice volumes from the Last Glacial Maximum to the Holocene. Proceedings of the National Academy of Sciences of the United States of America, 111 (43), 15296-15303. doi: 10.1073/pnas.1411762111

Lambert, F., Opazo, N., Ridgwell, A., Winckler, G., Lamy, F., Shaffer, G., .. A AbeOuchi, A. (2021). Regional patterns and temporal evolution of ocean iron fertilization and co2 drawdown during the last glacial termination. Earth and Planetary Science Letters, 554, 116675.

Lambert, F., Tagliabue, A., Shaffer, G., Lamy, F., Winckler, G., Farias, L., ... De Pol-Holz, R. (2015). Dust fluxes and iron fertilization in holocene and last glacial maximum climates. Geophysical Research Letters, 42(14), 6014-6023.

Lamy, F., Gersonde, R., Winckler, G., Esper, O., Jaeschke, A., Kuhn, G., ... Kilian, R. (2014). Increased dust deposition in the pacific southern ocean during glacial periods. Science, 343(6169), 403-407.

Lippold, J., Mulitza, S., Mollenhauer, G., Weyer, S., Heslop, D., \& Christl, M.

(2012). Boundary scavenging at the east atlantic margin does not negate use of $231 \mathrm{pa} / 230$ th to trace atlantic overturning. $\quad$ Earth and Planetary Science Letters, 333, 317-331.

Mahowald, N. M., Engelstaedter, S., Luo, C., Sealy, A., Artaxo, P., Benitez-Nelson, C., ... others (2009). Atmospheric iron deposition: global distribution, variability, and human perturbations. Annual review of marine science, 1, 245-278.

Mahowald, N. M., Muhs, D. R., Levis, S., Rasch, P. J., Yoshioka, M., Zender, C. S., \& Luo, C. (2006). Change in atmospheric mineral aerosols in response to climate: Last glacial period, preindustrial, modern, and doubled carbon dioxide climates. Journal of Geophysical Research Atmospheres, 111(10). doi: 10.1029/2005JD006653

Marcott, S. A., Bauska, T. K., Buizert, C., Steig, E. J., Rosen, J. L., Cuffey, K. M., .. Brook, E. J. (2014). Centennial-scale changes in the global carbon cycle during the last deglaciation. $\quad$ Nature, 514(7524), 616-619. $\quad$ doi: 10.1038 /nature13799

Marinov, I., Doney, S. C., \& Lima, I. D. (2010). Response of ocean phytoplankton community structure to climate change over the 21st century: partitioning the effects of nutrients, temperature and light. Biogeosciences, 7(12), 3941-3959. 
doi: 10.5194/bg-7-3941-2010

Mariotti, V., Bopp, L., Tagliabue, A., Kageyama, M., \& Swingedouw, D. Marine productivity response to Heinrich events: A model-data comparison. Climate of the Past, 8(5), 1581-1598. doi: 10.5194/cp-8-1581-2012

Martin, J. H. (1990). Iron Hypothesis of CO2 Change. Paleoceanography, 5(1), 113.

Martínez-Garcia, A., Rosell-Melé, A., Geibert, W., Gersonde, R., Masqué, P., Gaspari, V., \& Barbante, C. (2009). Links between iron supply, marine productivity, sea surface temperature, and co2 over the last 1.1 ma. Paleoceanography, 24(1).

Martínez-García, A., Sigman, D. M., Ren, H., Anderson, R. F., Straub, M., Hodell, D. A., ... Haug, G. H. (2014). Iron fertilization of the subantarctic ocean during the last ice age. Science, 343(6177), 1347-1350.

Matsumoto, K., Sarmiento, J. L., \& Brzezinski, M. A. ～(2002). Silicic acid leakage from the Southern Ocean: A possible explanation for glacial atmospheric p CO 2 . Global Biogeochemical Cycles, 16(3), 5-1-5-23. doi: $10.1029 / 2001 \mathrm{gb001442}$

McGee, D., Broecker, W. S., \& Winckler, G. (2010). Gustiness: The driver of glacial dustiness? Quaternary Science Reviews, 29(17-18), 2340-2350. Retrieved from http://dx.doi.org/10.1016/j.quascirev.2010.06.009 doi: 10.1016/ j.quascirev.2010.06.009

Meissner, K., McNeil, B. I., Eby, M., \& Wiebe, E. C. (2012). The importance of the terrestrial weathering feedback for multimillennial coral reef habitat recovery. Global Biogeochemical Cycles, 26(3), 1-20. doi: 10.1029/2011GB004098

Meissner, K., Weaver, A. J., Matthews, H. D., \& Cox, P. M. (2003). The role of land surface dynamics in glacial inception: A study with the UVic Earth System Model. Climate Dynamics, 21(7-8), 515-537. doi: 10.1007/ s00382-003-0352-2

Mengis, N., Keller, D., MacDougall, A., Eby, M., Wright, N., Meissner, K., .. Zickfeld, K. (2020). Evaluation of the University of Victoria Earth System Climate Model version 2.10 (UVic ESCM 2.10). Geoscientific Model Development, in press.

Menviel, L., Joos, F., \& Ritz, S. (2012). Simulating atmospheric co2, 13c and the marine carbon cycle during the last glacial-interglacial cycle: possible role for a deepening of the mean remineralization depth and an increase in the oceanic nutrient inventory. Quaternary Science Reviews, 56, 46-68.

Menviel, L., Yu, J., Joos, F., Mouchet, A., Meissner, K., \& England, M. Poorly ventilated deep ocean at the last glacial maximum inferred from carbon isotopes: A data-model comparison study. Paleoceanography, 32(1), 2-17.

Miklasz, K. A., \& Denny, M. W. (2010). Diatom sinking speeds: Improved predictions and insight from a modified Stoke's law. Limnology and Oceanography, 55(6), 2513-2525. doi: 10.4319/lo.2010.55.6.2513

Muglia, J., Somes, C. J., Nickelsen, L., \& Schmittner, A. (2017). Combined Effects of Atmospheric and Seafloor Iron Fluxes to the Glacial Ocean. Paleoceanography, 32(11), 1204-1218. doi: 10.1002/2016PA003077

Nair, A., Mohan, R., Manoj, M. C., \& Thamban, M. (2015). Glacial-interglacial variability in diatom abundance and valve size: Implications for Southern Ocean paleoceanography. Paleoceanography, 30(10), 1245-1260. doi: 10.1002/2014PA002680

Negre, C., Zahn, R., Thomas, A. L., Masqué, P., Henderson, G. M., MartínezMéndez, G., ... Mas, J. L. (2010). Reversed flow of atlantic deep water during the last glacial maximum. Nature, 468(7320), 84-88.

Nickelsen, L., Keller, D. P., \& Oschlies, A. (2015). A dynamic marine iron cycle module coupled to the University of Victoria Earth System Model: The Kiel Marine Biogeochemical Model 2 for UVic 2.9. Geoscientific Model Develop- 
ment, 8(5), 1357-1381. doi: 10.5194/gmd-8-1357-2015

Ohgaito, R., Abe-Ouchi, A., O'Ishi, R., Takemura, T., Ito, A., Hajima, T., ... Kawamiya, M. (2018). Effect of high dust amount on surface temperature during the Last Glacial Maximum: A modelling study using MIROC-ESM. Climate of the Past, 14(11), 1565-1581. doi: 10.5194/cp-14-1565-2018

Oka, A., Abe-Ouchi, A., Chikamoto, M. O., \& Ide, T. (2011). Mechanisms controlling export production at the lgm: Effects of changes in oceanic physical fields and atmospheric dust deposition. Global Biogeochemical Cycles, 25(2).

Pacanowski, R. C. (1995). MOM 2 Documentation, User's Guide and Reference Manual (Tech. Rep. No. 3). GFDL Ocean Group, Geophysical Fluid Dynamics Laboratory, Princeton, USA.

Pasquier, B., \& Holzer, M. (2018). The number of past and future regenerations of iron in the ocean and its intrinsic fertilization efficiency. Biogeosciences, 15(23), 7177-7203. doi: 10.5194/bg-15-7177-2018

Peltier, W. R. (1994). Ice Age Paleotopography. Science, 265(5169), 195-202.

Sarmiento, J. L., \& Gruber, N. (2006). Ocean biogeochemical dynamics. Princeton University Press.

Sarmiento, J. L., Slater, R., Barber, R., Bopp, L., Doney, S. C., Hirst, A. C., ... Stouffer, R. (2004). Response of ocean ecosystems to climate warming. Global Biogeochemical Cycles, 18(3). doi: 10.1029/2003GB002134

Schmittner, A., Oschlies, A., Giraud, X., Eby, M., \& Simmons, H. L. A global model of the marine ecosystem for long-term simulations: Sensitivity to ocean mixing, buoyancy forcing, particle sinking, and dissolved organic matter cycling. Global Biogeochemical Cycles, 19(3), 1-17. doi: 10.1029/2004GB002283

Schmittner, A., \& Somes, C. J. (2016). Complementary constraints from carbon (13c) and nitrogen (15n) isotopes on the glacial ocean's soft-tissue biological pump. Paleoceanography, 31(6), 669-693.

Schroth, A. W., Crusius, J., Sholkovitz, E. R., \& Bostick, B. C. (2009). Iron solubility driven by speciation in dust sources to the ocean. Nature Geoscience, 2(5), 337-340.

Semtner, A. J. (1976). A Model for the Thermodynamic Growth of Sea Ice in Numerical Investigations of Climate (Vol. 6) (No. 3). doi: 10.1175/ 1520-0485(1976)006 $\langle 0379:$ amfttg $\rangle$ 2.0.co;2

Shoenfelt, E. M., Winckler, G., Lamy, F., Anderson, R. F., \& Bostick, B. C. (2018). Highly bioavailable dust-borne iron delivered to the southern ocean during glacial periods. Proceedings of the National Academy of Sciences, 115(44), 11180-11185.

Sigman, D. M., \& Boyle, E. A. (2001). Antarctic stratification and glacial co 2. Nature, 412(6847), 606-606.

Sigman, D. M., Fripiat, F., Studer, A. S., Kemeny, P. C., Martínez-García, A., Hain, M. P., ... Haug, G. H. (2020). The southern ocean during the ice ages: A review of the antarctic surface isolation hypothesis, with comparison to the north pacific. Quaternary Science Reviews, 106732.

Simon, N., Cras, A. L., Foulon, E., \& Lemée, R. (2009). Diversity and evolution of marine phytoplankton. Comptes Rendus - Biologies, 332(2-3), 159-170. Retrieved from http://dx.doi.org/10.1016/j.crvi.2008.09.009 doi: 10.1016/j.crvi.2008.09.009

Skinner, L. C., Fallon, S., Waelbroeck, C., Michel, E., \& Barker, S. (2010). Ventilation of the deep southern ocean and deglacial co2 rise. Science, 328(5982), 1147-1151.

Somes, C. J., Schmittner, A., Muglia, J., \& Oschlies, A. (2017). A three-dimensional model of the marine nitrogen cycle during the last glacial maximum constrained by sedimentary isotopes. Frontiers in Marine Science, 4(MAY), 1-24. doi: 10.3389/fmars.2017.00108 
Studer, A. S., Sigman, D. M., Martínez-García, A., Benz, V., Winckler, G., Kuhn, G., ... others (2015). Antarctic zone nutrient conditions during the last two glacial cycles. Paleoceanography, 30(7), 845-862.

Waelbroeck, C., Paul, A., Kucera, M., Members, M. P., Rosell-Melé, A., Weinelt, M., ... others (2009). Constraints on the magnitude and patterns of ocean cooling at the last glacial maximum. Nature Geoscience, 2(2), 127.

Weaver, A. J., Eby, M., Wiebe, E. C., Bitz, C. M., Duffy, P. B., Ewen, T. L., ... Yoshimori, M. (2001). The UVic earth system climate model: Model description, climatology, and applications to past, present and future climates. Atmosphere-Ocean, 39(4), 361-428. Retrieved from http:// www.tandfonline.com/doi/abs/10.1080/07055900.2001.9649686 doi: 10.1080/07055900.2001.9649686

Yamamoto, A., Abe-Ouchi, A., Ohgaito, R., Ito, A., \& Oka, A. (2019). Glacial $\mathrm{CO}<$ sub $>2</$ sub $>$ decrease and deep-water deoxygenation by iron fertilization from glaciogenic dust. Climate of the Past Discussions(March), 1-31. doi: 10.5194/cp-2019-31

Yao, W., Kvale, K., Achterberg, E., Koeve, W., \& Oschlies, A. (2019). Hierarchy of calibrated global models reveals improved distributions and fluxes of biogeochemical tracers in models with explicit representation of iron. Environmental Research Letters, 14 (11), 114009.

Zhang, Y., Mahowald, N., Scanza, R. A., Journet, E., Desboeufs, K., Albani, S., ... Fomba, K. W. (2015). Modeling the global emission, transport and deposition of trace elements associated with mineral dust. Biogeosciences, 12(19), 5771-5792. doi: 10.5194/bg-12-5771-2015 